\title{
Disturbance and distributions: avoiding exclusion in a warming world
}

\author{
Douglas Sheil $^{1}$
}

\begin{abstract}
I highlight how disturbance determines species distributions and the implications for conservation practice. In particular, I describe opportunities to mitigate some of the threats to species resulting from climate change. Ecological theory shows that disturbance processes can often slow or prevent the exclusion of species by competitors and that different disturbance regimes result in different realized niches. There is much evidence of disturbance influencing where species occur. For example, disturbance can lower the high elevation treeline, thus expanding the area for high elevation vegetation that cannot otherwise persist under tree cover. The role of disturbance in influencing interspecific competition and resulting species persistence and distributions appears unjustly neglected. I identify various implications, including opportunities to achieve in situ conservation by expanding plant species ranges and reducing species vulnerability to competitive exclusion. Suitable frequencies, scales, intensities, spatial configurations, and timings of the right forms of disturbance can improve the persistence of targeted species in a wide range of contexts. Such options could reduce the extinctions likely to be associated with climate change. More generally, these mechanisms and the resulting realizable niche also offer novel insights to understanding and manipulating species distributions.
\end{abstract}

Key Words: coexistence; competition-colonization trade-off; competitive displacement; competitive hierarchy; elevation; intermediatedisturbance-hypothesis; source-sink dynamics; succession

\section{INTRODUCTION}

Disturbance, a temporary reduction in competition, influences where species can persist. Conservationists use grazing, mowing, weeding, biomass removal, clearing, burning, and cutting to generate the conditions required to maintain plant communities and species that might otherwise be displaced. Such interventions provide a powerful and flexible means to manipulate plant communities and species distributions. Controlled burning, for example, has long been used to generate and maintain desirable vegetation by controlling the location, frequency, scale, timing, and intensity of burns (Bell 2001, Parr and Andersen 2006). Grazing and mowing are used in the restoration and maintenance of native vegetation: examples include chalk grassland (Bobbink and Willems 1993) and tidal marshes in the Netherlands (Bakker 1978), coastal dune grasslands in Wales (Hewett 1985), tall grass prairie in Kansas (Collins et al. 1998), and native California grasslands (Menke 1992). Similarly, conservation-oriented forest management emphasizes interventions that seek to replicate natural disturbance processes and outcomes (see for example, Kuuluvainen 2009, Long 2009, Perera and Cui 2010). Such interventions appear distinct from those required under rapid climate change.

Climate change is among the world's most urgent conservation problems. Mass extinctions may be imminent (Thomas et al. 2006, Colwell et al. 2008, Urban et al. 2012, Cahill et al. 2013) and even the most common species are at risk (Warren et al. 2013). Rather than simulating natural conditions, any in situ conservation will likely require species to be maintained within novel communities under the conditions resulting from climate change (see Urban et al. 2012).

Conservationists have identified few practical interventions to maintain species in a rapidly warming climate. Most in situ proposals focus on minimizing other (nonclimatic) day-to-day threats as well as on facilitating dispersal by improving large-scale connectivity (Loarie et al. 2009, Mawdsley et al. 2009). Such efforts are unlikely to prevent the majority of extinctions. Many species appear unlikely to move to cooler (higher) elevations or latitudes at the rate needed to track temperature changes (Wright et al. 2009, Corlett and Westcott 2013). Along with ex situ options, moving threatened species to new locations, i.e., translocation, managed relocation, or assisted colonization, is increasingly proposed despite associated costs and risks (Hoegh-Guldberg et al. 2008, Ricciardi and Simberloff 2009). As Minteer and Collins (2010:1804) noted: "we have a rapidly shrinking set of options for saving many species threatened by a warming world. The biological stakes are high. If we value wild species and wish to bequeath a significant fraction of global biodiversity to future generations, radical strategies like managed relocation may well be our last best chance."

My goal is to highlight some neglected options for understanding species distributions and for achieving conservation. The terms defined in Table 1 clarify their use here. I first introduce and review some established ecological concepts. The implications of these concepts are important. These implications are often overlooked though they offer opportunities for conservation. I highlight how disturbance can expand species' distribution limits on a temperature gradient. I show that, despite neglect, there is evidence supporting these ideas. I then consider how competitive exclusion can be reduced and the options this provides for conservation practice. Finally, I examine the further integration of disturbance ecology into distribution science and the practice of conservation.

\section{CONCEPTS AND THEORY}

This section outlines some basic ecological concepts. These concepts provide the theoretical foundations for the subsequent proposals, evaluations, and discussions. Readers already familiar with these topics should skip to the following section.

Competition limits species' persistence in plant communities (Connell 1978, Tilman 1990, Amarasekare 2003, Silvertown 
Table 1. Glossary of concepts used in the main text.

\begin{tabular}{|c|c|}
\hline Concept & Explanation \\
\hline Coexistence & The ability of species to persist in the presence of each other. \\
\hline Competition & $\begin{array}{l}\text { An interaction between organisms in which the fitness (survival and reproduction) of one, or } \\
\text { more, is reduced. }\end{array}$ \\
\hline Competitive displacement & $\begin{array}{l}\text { Occurs when a species cannot persist within some part its fundamental niche because of } \\
\text { competition with one or more other species (see competitive exclusion). }\end{array}$ \\
\hline Competitive exclusion & Occurs when a species cannot persist because of competition with one or more other species. \\
\hline Competitive hierarchy & $\begin{array}{l}\text { A set of competing species with overlapping fundamental niches that segregate along a } \\
\text { gradient. }\end{array}$ \\
\hline Disturbance & $\begin{array}{l}\text { An event involving a loss or rapid redistribution of biomass that releases space and/or other } \\
\text { resources that species require (thus reducing some aspects of competition). }\end{array}$ \\
\hline Disturbance regime & $\begin{array}{l}\text { The pattern of disturbance events in time and space that characterize a given area (typically } \\
\text { with predictable elements). If the pattern cannot be predicted, or includes unique events (on } \\
\text { the time scale used), this would be part of the description. }\end{array}$ \\
\hline Fugitive species & A species that will be eliminated by other species if competition is sustained. \\
\hline Fundamental niche & $\begin{array}{l}\text { The environmental conditions under which a given species can survive and sustain } \\
\text { population growth in the absence of other species. }\end{array}$ \\
\hline Niche space & The range of available conditions (where organisms could occur). \\
\hline Occurrence & $\begin{array}{l}\text { When species are observed without necessarily inferring anything about their ability to } \\
\text { persist. }\end{array}$ \\
\hline Realizable niche & The degree to which the realized niche can be made broader by interventions. \\
\hline Realized niche & $\begin{array}{l}\text { The environmental conditions under which a given species can survive and sustain } \\
\text { population growth in the presence of other species. }\end{array}$ \\
\hline Source-sink dynamics & $\begin{array}{l}\text { Processes permitting the occurrence of a species in one location (the sink) to depend on } \\
\text { dispersal from other locations (the source). }\end{array}$ \\
\hline Stabilizing mechanism & $\begin{array}{l}\text { A process increasing the ability of a population to recover following deviations even to low } \\
\text { density. }\end{array}$ \\
\hline Trade-off & $\begin{array}{l}\text { When the presence of, or investment in, one species trait, behavior, or ability implies the loss } \\
\text { of, or decreased investment in, another. For example, if the ability to withstand lower } \\
\text { temperatures implied a reduced ability for rapid growth at higher temperatures. }\end{array}$ \\
\hline
\end{tabular}

2004). When the population growth of more than one species is limited by space, light, or any resource, competition is inevitable. When a species cannot persist with a competitor, it may be eliminated locally, a process known as competitive exclusion. All species are vulnerable to exclusion by superior competitors.

Species distributions observed in nature generally encompass a narrower range of environmental conditions than implied by the species' physiological tolerances. This is a result of competitive displacement, i.e., realized niches tend to be narrower than fundamental niches (Vandermeer 1972, Colwell and Fuentes 1975, Soberón 2007).

The species that are competitive dominants under the most benign conditions are seldom the same as those that dominate in less benign conditions (Keddy and Shipley 1989, Wisheu 1998). Often, these latter species will also become established and grow well in more benign sites if the other species are absent. Thus, what appear to be colonizing species in some locations seem to behave as late successional species in less hospitable environments (van Steenis 1958, Budowski 1965, Oldeman 1990). Competitive displacement has also been invoked to explain why species are often most abundant under environmental conditions that appear suboptimal for their growth (Cabral and Kreft 2012, McGill 2012). In any case, the species that dominate in marginal sites can often become established, grow, and persist in better sites only if they don't have to compete with species that can otherwise displace them under these conditions.

Study of such context-dependent competition has led to the recognition of sequential displacement patterns, or competitive hierarchies, in which species segregate along gradients (Keddy and Shipley 1989, Smith and Huston 1990, Silvertown and Dale 1991, Wisheu 1998). Such patterns suggest some trade-off in which species can have superior tolerance of certain situations or superior competitive abilities in other situations, but cannot have both. Many species possess adaptations conferring tolerance of conditions without being dependent on them, for example, plants that tolerate saline (Barbour 1970, Gilbert and Fraser 2013) or metal rich soils (Maestri et al. 2010, Serrano et al. 2015) can usually grow without these salts and metals. Similar patterns occur for temperature: for example, frost tolerance does not imply frost dependence.

Disturbance can be defined in many ways even by ecologists (see for example, Sheil 1999). In the present context, I propose a definition that implies reduced competition. Such events thus modify each species' competitive environment and influence the realized niches and resulting distributions. In Appendix 1, I select a range of examples that show that disturbance often permits species to range beyond their more typical environmental conditions. 
Various aspects of ecological theory address disturbance and the mechanisms that permit species coexistence. I am concerned with how competition can be reduced, thus reducing the threat to a given species, rather than with the formal requirements of sustained coexistence. Nonetheless, ecological theory offers useful insights. Elimination by competition can be avoided through opportunities in time and typically relies on life stages that avoid competition, e.g., seeds that only germinate in open sites (Grubb 1977, Martorell and Freckleton 2014). Elimination by competition can also be avoided through opportunities in space, such as in "between-patch" models in which species can become extinct in one patch, but recolonization can occur from asynchronous-successional patches (Warner and Chesson 1985, Tilman 1990, Levine and Rees 2002). Intensity, extent, pattern, and frequency of disturbance can be tuned to maintain, or eliminate, species depending on their attributes (Connell 1978, Miller 1982, Malanson 1984, Shea et al. 2004, Banitz et al. 2008, Miller et al. 2011). Low levels of disturbance favor slow-growing species with high resilience to competition. Increasing disturbance frequency favors species with more rapid life cycles. Large-scale disturbances favor good colonization abilities. Even the composition of a highly disturbed community can be influenced by additional disturbance (Chesson and Huntly 1997 , Violle et al. 2010).

Exclusion is well studied in simple diversity-disturbance models in which all but the most competitive species are considered fugitive species; these persist only by avoiding the sustained competition that would otherwise eliminate them. Under some disturbance regimes species coexist in a stable manner, whereas in others species are lost. The theory of such coexistence mechanisms have been rigorously examined elsewhere (e.g., Chesson 2000). Persistence for the fugitives requires both sufficient opportunities to avoid competition and a stabilizing mechanism to ensure small populations can grow. Often this stabilizing mechanism involves a trade-off between competitive abilities and each species' colonization and dispersal abilities, which confer a short-term advantage to the fugitive in terms of access to low competition sites (Amarasekare 2003).

Abstract theories are challenging to apply in the real world. For example, an observation that a species occurs somewhere says relatively little about its ability to persist in that location. The occurrence may represent a relic, a chance ephemeral occurrence, or a sink population (see source-sink dynamics in Table 1). Such fundamental challenges explain why ecological-coexistence theory has had little influence on conservation practice. Despite its focus on species persistence, such theory is hard to apply in practice. Demonstrations that species coexist in a persistent manner, rather than simply noting their occurrence in the same location, remain rare even in formal ecological studies (Siepielski and McPeek 2010). Despite its intuitive appeal, achieving demonstrable coexistence as ecologists might define it, is neither a practical nor a realistic conservation goal. Nevertheless, given that conservation can use any cost-effective combination of actions that can slow or prevent species loss, there is value in recognizing the conditions under which competitive exclusion is more or less probable or rapid. Coexistence theory thus offers some potentially useful insights about the role of disturbance.

Unlike simplified theoretical models in which disturbance involves uniform clearing of space ready for colonization, real disturbances are usually complex, messy, partial, and selective.
For example, the form and intensity of the disturbance can have strong discriminating effects, e.g., the effects of drought, fire, elephant damage, and wind on forest trees are not uniform, but depend among other things on the traits of species and individuals (Everham and Brokaw 1996, Sheil and Salim 2004, van Nieuwstadt and Sheil 2005, Keeley et al. 2011, Webb et al. 2014). Disturbance type can also be selective in other ways, such as species responding to fire for seed release (He et al. 2011) and to smoke for germination (Tormo et al. 2014). Subtle differences within processes can also be selective, as in grazing, browsing, and trampling in which different animals influence vegetation in distinct ways (see Stebbins 1981, Spear and Chown 2009). Of course many additional ecological processes, contingencies, and legacies influence outcomes (Pickett et al. 1987, White and Jentsch 2001, Nuttle et al. 2013, Supp and Ernest 2014, Zobel and Öpik 2014). The point is that disturbance can slow or prevent exclusion in multiple ways. For a given species in a given setting (competing species included), there will generally be some optimal regime, whereas too much or too little disturbance will result in loss. I focus on choices slowing or preventing the loss of targeted species, noting that the principles also have potential for the control and elimination of undesirable species. Key processes include freeing up space and resources, a reduction in the competitively superior species, and a sufficiently greater payoff for the competitively inferior species.

Although climatic tolerances limit potential species ranges (Somero 2011, Huey et al. 2012), interactions among species determine many actual distributions (Sexton et al. 2009, McCain and Colwell 2011, Wisz et al. 2013, Kubisch et al. 2014, Svenning et al. 2014). These interspecific interactions are considered a proximate cause of distribution change with climate change (Keeley et al. 2011, Urban et al. 2012, Cahill et al. 2013). This is another way of concluding that competition modifies the realized niche. Realized niches play a central role in modern distribution modeling. Although much has been said concerning the shortcomings of such approaches, such as dispersal barriers and biotic dependencies (see, e.g., Davis et al. 1998, Guisan and Thuiller 2005, Trivedi et al. 2008, Wiens et al. 2009, Araújo and Peterson 2012), and the need to investigate and understand fundamental niches has been highlighted (e.g., Guisan and Rahbek 2011), disturbance processes appear neglected in this context.

A species' realized niche depends on interactions with other species. When competition is strong, the niche will be smaller; when competition is weaker it will be larger. What is realizable depends not only on the other species present but also on disturbance regimes. A schematic model for one species with and without some specific disturbance intervention is shown in Figure 1. Such interventions can expand the habitat available to the species or increase persistence in a modified climate, if the situation in Figure 1b became that in Figure 1c. I shall not explore every complexity of plant community ecology, but I note that some ecological phenomena, such as positive interactions (as in Bronstein 1994, Brooker et al. 2008) and density dependent lifehistory parameters (Petermann et al. 2008, Mangan et al. 2010), can reduce competitive exclusion and expand realized niches. The principle that different disturbance regimes result in different realized niches still applies. The implication is that, to the extent that distributions can be reduced by competitive exclusion, these distributions might be increased by suitable interventions such as burning, grazing, mowing, or tree cutting. 
Fig. 1. Hypothetical example of a niche space defined for two variables. The conditions that can support the species when growing alone define its fundamental niche space (yellow). The conditions that can support the species when growing in a community define the actual or realized niche (dark green). However, the extent of this range can be modified by interventions (i.e., modifications to the disturbance regime and related processes such as weeding) that modify the competitive environment to generate a different realized niche (light green); both realized niches cover different portions of the larger fundamental niche (a). Figures (b) to (e) conform to the labels in Figure (a) and illustrate different scenarios in terms of locally available habitat (range of environments bounded by the dotted line; for simplicity we assume that the actual physical area is evenly distributed across the environmental space within the bounded areas). In (b), available habitat matches well to the species' needs and the intervention offers little benefit. In (c) the intervention improves the use of the available habitat. In (d), even though much of the habitat lies within the fundamental niche of the species, the intervention has only a marginal chance of maintaining the species, although it may nonetheless slow losses. In (e), neither prevailing conditions nor the intervention allow the species to persist although it may slow species loss; translocation is needed to an area with the properties within the red dotted line.
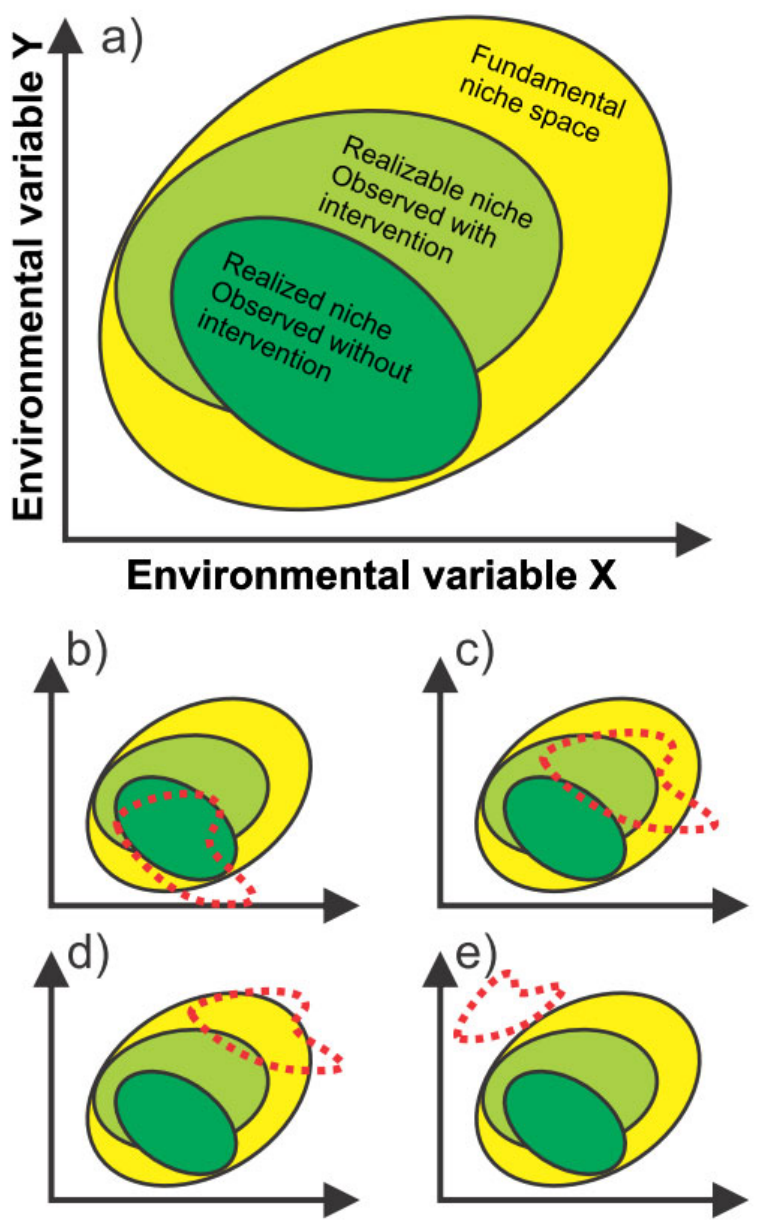

\section{ELEVATION AND SUCCESSION}

Environmental conditions play a more direct role in determining the upper than the lower elevation boundaries for many species. For example, frost tolerance determines the upper-elevation limit of numerous plant species (Ohsawa 1995, Ricklefs 2005, Preston and Sandve 2013). Climatic limits can also be inferred from the inability of species to maintain positive population growth above their high-elevation limits even in the absence of competitors (e.g., HilleRisLambers et al. 2013). At the lower elevation limits, interspecific competition appears more influential (Urban et al. 2012, HilleRisLambers et al. 2013). These generalizations are supported by various studies; one recent review of species transplant studies has noted that highelevation range limits are more likely to be determined solely by abiotic factors than are low-elevation limits ( $82 \%$ of 38 tests and $45 \%$ of 20 tests, respectively; Hargreaves et al. 2014). Similar patterns have also been inferred for the elevation ranges of bryophytes (Cleavitt 2004). These results do not mean that biotic processes play no role in defining upper elevation limits (Brown and Vellend 2014), only that these tend to be weaker and harder to detect.

The implication is that upper elevation limits depend more on environmental tolerance and lower elevation limits depend more on competition. This indicates a prevalent trade-off in which a species' tolerance of colder (higher elevation) conditions implies a cost in terms of reduced competitive abilities under warmer (lower elevation) conditions. Such trade-offs generate a competitive hierarchy.

Consider a mountain supporting three model species with overlapping elevation ranges (Fig. 2a, b). Sustained competition narrows the range of conditions under which the species occur but a suitable disturbance regime can counteract this effect and permit all three species to become established over a broader range of environments (Fig. 2c). At higher elevation, only the species tolerant of low temperatures can become established (Fig. 2d), but all three species can become established, grow, and compete following sufficient disturbance at some lower elevations (Fig. 2e, f). The first plants to become established at a site gain an advantage over competitors and may persist long enough to reproduce (see, e.g., Weiner 1990, Belyea and Lancaster 1999). Thus, if they are present, higher elevation species may occur transiently and may dominate (Fig. 2e) or not (Fig. 2f).

Disturbance determines distributions. At sufficiently low levels of disturbance, succession proceeds and less competitive species are locally excluded. At sufficiently high levels of disturbance, species are unable to persist at any elevation. Then there is an intermediate level of disturbance in which upper and lower species boundaries, and overall elevation range, are maximized; these peaks do not necessarily align within or among the species involved (Fig. 2g, h).

A simple illustration of the overall processes by which higher elevation species might persist for longer under a warming climate in a more disturbed versus a less disturbed system is provided in Figure 3. The finite elevation in the mountain scenario illustrates a more general situation in which species cannot disperse to a more suitable environment, and persistence depends on enduring a changed climate rather than on dispersal. 
Fig. 2. Schematic distribution, succession, and disturbance relationships of three idealized species on a temperature (reverse elevation) gradient. Their fundamental niches (a) are broader than their realized niches (b), but with disturbance, species cover a broader range of conditions and competition is reduced (c), peaks are lower because limited space and more species implies reduced mean likelihood of any one species occurring at any one location. At high elevation, only one of the three species can tolerate the low temperatures (d); at lower elevation all three species can become established and competition subsequently leads to exclusion and thus succession (e and f). If there is no competition, disturbance has little impact on species distributions until high frequency and/or intensities interfere with species being able to complete their life cycle (g); species occur only within the concave lines of their color. When species compete as a competitive hierarchy, moderate disturbance leads to a less constrained distribution and to improved persistence at both higher and lower elevations than would otherwise occur (h). Figures (e) and (f) highlight that there may be a trade-off in which high elevation species are better colonists (a pattern observed in many tropical mountains (e), or not (f), but in both cases there is a period in which high elevation species can establish and pre-empt space at low elevations). This assumes dispersal but note that under climate change, reaching warmer sites is a matter of persistence over time. The arrows in (a) labeled with a red (d), (e), and (f) indicates the approximate location on the elevation of the succession shown in figures (d), (e), and (f), respectively. It is important to note the limitation of presenting disturbance on a single axis and uniformly for an entire gradient. In reality, we can modify many aspects of disturbance and decide whether such changes are uniform or targeted more locally.

\section{Distribution}

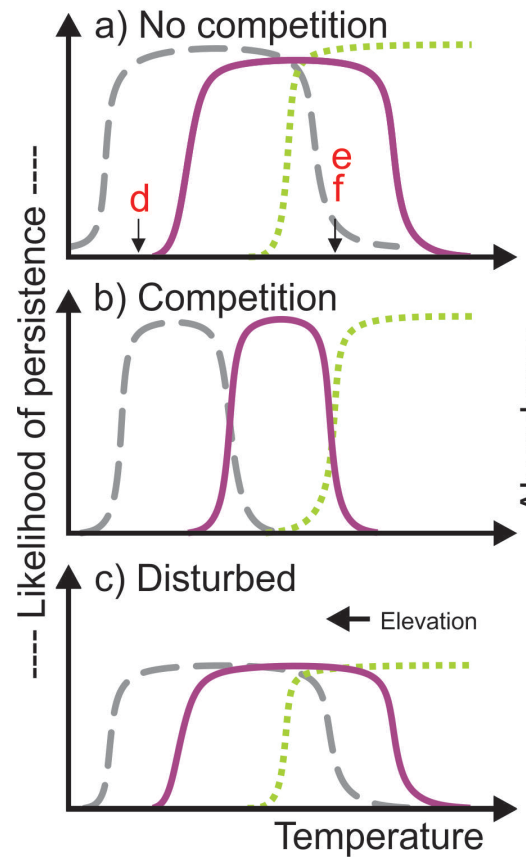

Succession

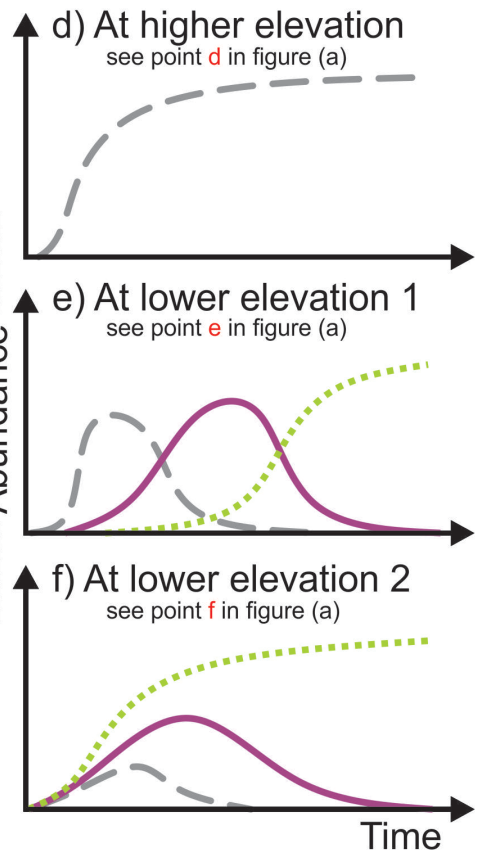

Disturbance response

g) No competition

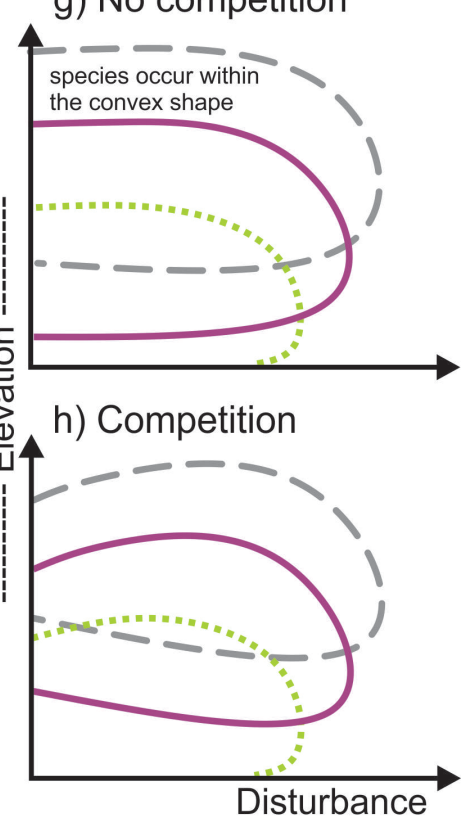

Analogous situations arise in which coastlines, deserts, or other barriers to migration occur, and species have to persist in a modified climate. Furthermore, whenever environmental change occurs more rapidly than a given species can track through dispersal, similar disturbance-based interventions may prove useful to reduce species losses due to exclusion.

\section{EVIDENCE}

The significance of competition for species persistence under climate change has long been recognized (e.g., Woodward 1992). Various reviews have concluded that competition among species often determines climate-induced extinctions (Jankowski et al. 2010, Sinervo et al. 2010). Notably, the handful of welldocumented extinctions already attributed to climate change have all involved interspecific interactions (Cahill et al. 2013), whereas simulation studies also report increased rates of extinction when competition is explicitly included (Urban et al. 2012).

Fewer studies have examined the impact of disturbance on how species are distributed with respect to elevation or temperature. Nonetheless, relevant observations show that disturbance permits species to occur in both cooler and warmer conditions than otherwise (see Appendix 1 for a more detailed account of such observations). Some of these cases appear well established: for example, there is recognition that disturbance has lowered the treeline in many highland regions, thereby permitting nonforest communities to occur at lower elevations than otherwise (Hamilton and Perrott 1981, Smith and Young 1987, Korner 1998, Hemp 2006, Olivera et al. 2009, White 2013). 
Table 2. Seven conditions for which violation will slow or prevent competitive exclusion among species with potential violations and options provided through disturbance or other interventions (based on Palmer 1994).

\begin{tabular}{|c|c|}
\hline Conditions & Example violation option(s) \\
\hline $\begin{array}{l}\text { Time has been sufficient to allow } \\
\text { exclusion }\end{array}$ & $\begin{array}{l}\text { Interruptions to prevent sustained competition. Examples include any frequent opening up } \\
\text { of habitat, such as might be maintained by frequent burning or cutting. }\end{array}$ \\
\hline $\begin{array}{l}\text { The environment is temporally } \\
\text { constant }\end{array}$ & $\begin{array}{l}\text { The environment is regularly changed. This can be achieved by changing any process over } \\
\text { time, such as might be achieved by allowing periods of grazing and recovery. }\end{array}$ \\
\hline $\begin{array}{l}\text { The environment has no spatial } \\
\text { variation }\end{array}$ & $\begin{array}{l}\text { Spatial heterogeneity generated. Any process that can be implemented unevenly in space } \\
\text { qualifies. With burning, it could, for example, require the use of firebreaks to protect some } \\
\text { areas or the gathering of fuel in some areas to burn more intensely and leave more ash. }\end{array}$ \\
\hline Growth is limited by one resource & $\begin{array}{l}\text { Multiple key resources need to be limited. Applications would be context specific but the } \\
\text { redistribution of biomass and associated nutrients can lead to local gradients in multiple key } \\
\text { resources. }\end{array}$ \\
\hline $\begin{array}{l}\text { Rare species are not } \\
\text { disproportionately favored in terms } \\
\text { of survivorship, reproduction, or } \\
\text { growth }\end{array}$ & $\begin{array}{l}\text { Selective reduction of more common or more competitive species. This can be achieved by } \\
\text { selecting the type of disturbance that has an impact on dominant species; for example, fire } \\
\text { against thin barked species, browsing against palatable species. Selective cutting or weeding } \\
\text { is also a way to favor certain species over others. }\end{array}$ \\
\hline $\begin{array}{l}\text { Species have the opportunity to } \\
\text { compete }\end{array}$ & $\begin{array}{l}\text { Species can be segregated (in time and/or space). Individuals or subpopulations can be } \\
\text { maintained in small unmixed patches. This requires control of unwanted regeneration, i.e., } \\
\text { cutting, weeding, mulching. }\end{array}$ \\
\hline There is no immigration & $\begin{array}{l}\text { Assisted dispersal, enrichment planting, intensive maintenance of viable source populations, } \\
\text { connectivity maintained. Spatial configuration can be developed to favour effective } \\
\text { dispersal. }\end{array}$ \\
\hline
\end{tabular}

Fig. 3. Schematic illustration of vegetation zones on a mountain determined by an elevation temperature gradient (green lower, darker purple mid, and grey upper) with minor (above) and major (below) disturbances. A greater frequency of disturbance increases the elevation range covered by the vegetation zones (in so far as dispersal allows). If disturbance was increased sufficiently, the three species would, one by one, be eliminated entirely (not illustrated).

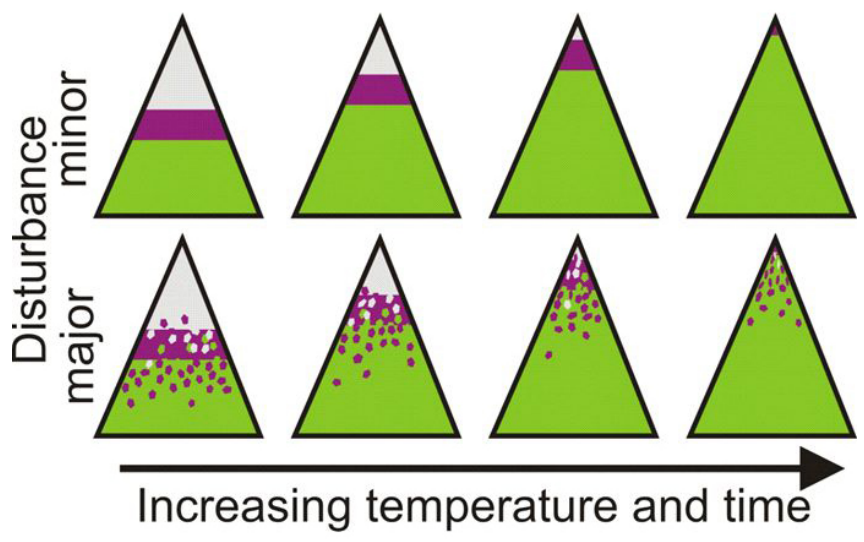

Other examples also indicate that, following disturbance, species are observed at lower elevations. For example, observations in Costa Rica show that the regrowth, which develops following forest clearance near the high elevation treeline, includes many nonforest species from higher elevations (Kappelle et al. 1995). In many such observations, the species possess the early successional characteristics required to disperse to and colonize open locations, i.e., small seeds, good dispersal, rapid maturity, and shade intolerance. There are exceptions, such as the African forest tree Ocotea usambarensis (Lauraceae), which occurs at lower elevations as part of secondary regrowth, but would generally be judged to be late successional, i.e., slow growing, long lived, large seeded, dense timbered, and shade tolerant. Lovett (1996:664) examined vegetation-elevation relationships in the Tanzanian highlands and commented that $O$. usambarensis, and by implication other species, are "restricted to higher elevations because of competitive community dynamics, and not as a result of physical factors such as temperature." Additional observations and evidence are provided in Appendix 1.

\section{OPTIONS}

Conservationists seeking to protect species threatened by competition, whether due to climate change or other factors, are interested in how exclusion can be reduced rather than the specific conditions allowing species to coexist in a formal sense. Nonetheless, coexistence theory offers various options for combating competitive exclusion. Palmer (1994) identified seven conditions that, if strictly met, permit competitive exclusion; all of these conditions may be influenced by disturbance regimes (Table 2, first column). Violation of these conditions can delay, reduce, or prevent competitive exclusion (Table 2, second column). For example, we might selectively remove the most competitive species, thus violating conditions five and six. An example is the weeding required to maintain native vegetation in Mauritius in the presence of competitively superior alien species (Monty et al. 2013). Or, to give a nondisturbance example, we might sustain a population by active seeding, enrichment planting, or translocation (violating condition seven). Put simply, competitive exclusion may be reduced in multiple ways, and disturbance processes can contribute to many of these. 


\section{DISCUSSION}

Theory shows that modification of a disturbance regime may permit species to occur, persist, or decline less rapidly, beyond their normal environmental range, e.g., outside the elevation and temperature conditions in which they occur and persist when observed in relatively pristine habitats. There is also evidence of such effects (Appendix 1). The realized niche of a species is malleable and depends on the species present and the disturbance regime.

Consider where highland treelines occur at lower elevations because of disturbance. This increases the habitat available to nonforest species, which cannot persist under tree cover and would be vulnerable to elimination by forest advance under a warming climate. Both the distribution and local persistence of these cover-sensitive species and the trees that would displace them depend on disturbance. Such examples illustrate how distribution ecologists and conservationists could benefit from a fuller understanding of disturbance processes.

\section{Implications for distribution ecology}

Whenever it has been studied, disturbance has been seen to influence plant distributions: for example, at local scales when facilitating the invasion of one species of Californian tarweed (Asteraceae) into the habitat of others (Harrison et al. 2010) or at larger scales when modeling plant distributions in dryland Australia (Fordham et al. 2012). Disturbance histories are also recognized as key to understanding vegetation patterns worldwide (Johns 1986, Clark 1996, Chiarucci et al. 2010, Gennaretti et al. 2014). Furthermore, theory shows that disturbance can determine whether or not species coexist in ecological communities or are eliminated. Focusing on elevation patterns, we can find observations showing that disturbance influences local distributions (e.g., Virtanen et al. 2010, Grytnes et al. 2014), yet disturbance is often ignored in reviews of what determines elevation patterns (e.g., McCain and Grytnes 2001). If the role of biotic interactions in determining distributions along environmental gradients requires investigation, as argued by Wisz et al. (2013), then greater attention to disturbance is essential.

Why have disturbance-induced elevation shifts in species distribution not been reported and investigated more systematically? Perhaps such patterns are obscured by other processes and interactions (e.g., mutualistic interactions; Bronstein 1994, Stanton-Geddes et al. 2012) or are hidden by the distribution of the disturbance processes (e.g., Sassen and Sheil 2013, Zhang et al. 2013). Perhaps the effects appear trivial. However, if a species can become established 800 metres lower than would be the case without disturbance, e.g., Helichrysum vegetation on Kilimanjaro (Hemp 2006), such a range extension implies a shift of around $5^{\circ} \mathrm{C}$ or a latitudinal shift in the order of $700 \mathrm{~km}$ ignoring dispersal barriers (Jump et al. 2009). Rather than being trivial, such a shift could avoid the extinctions likely with a $4^{\circ} \mathrm{C}$ increase in temperature. Neglect of such possibilities, once noted, is perplexing.

A focus on disturbance offers new hypotheses in distribution ecology as well as new tools for manipulating distributions. Observations show some species shifting down elevation gradients (Crimmins et al. 2011). Such shifts are generally viewed as puzzling in the context of warming trends and are interpreted as caused by a change in moisture availability, but disturbance provides an alternative explanation. Disturbance might also help explain why downslope shifts are common among alpine species on mountains frequented by people (see, e.g., Grytnes et al. 2014).

An improved appreciation of disturbance ecology may also illuminate biogeography (Rozendaal et al. 2010). For example, the arrival of many temperate species into Africa's highlands during the quaternary remains enigmatic because despite prolonged glacials, temperatures were never low enough to permit dispersal via the intervening lowlands (Morley 2000, Olago 2001, Wu et al. 2007, Gehrke and Linder 2009). Perhaps at some point during the drought- and fire-prone glacials, disturbance provided competition-free corridors or steppingstones through the lowlands (see, e.g., Daniau et al. 2010). In Europe, some alpine species appear to have persisted at low elevations since the last glacial (Pigott and Walters 1954). Others have highlighted the role of thin soils in maintaining suitable locations for these alpines (Birks and Willis 2008), but again I suggest that disturbance regimes, i.e., grazing, burning, and forest clearance, have likely played a significant role.

Ecological theorists have helped identify how competitive exclusion can be reduced; in return I propose disturbance and competitive hierarchies on environmental gradients merit attention from theorists. The simple theory advanced in Figure 2 and illustrated in Figure 3 has consequences for local and regional species coexistence and diversity. Where fundamental niches overlap, an intermediate disturbance-type behavior will operate. This behavior refers to the intermediate disturbance hypothesis, meaning that species coexist and richness is maximized at some intermediate level of disturbance, i.e., too little allows exclusion and too much prevents one or more species from maintaining positive population growth (Connell 1978, Sheil and Burslem 2003, Shea et al. 2004). This deceptively simple idea involves many complexities. Various aspects have been discussed in detail elsewhere (see, e.g., Wilson 1994, Chesson 2000, Miller et al. 2011, Fox 2013, Sheil and Burslem 2013, Huston 2014). Nonetheless, the influence of extended gradients and competitive hierarchies upon such relationships appears unexplored, although I speculate that these may reflect significant aspects of many natural systems. The gradient can help stabilize the presence of many species by ensuring that each maintains population growth somewhere in the wider landscape. As long as such populations persist, many species may occur largely as sink populations in the wider landscape (Pulliam 2000). The generation and persistence of such source populations would be the focus of any conservation interventions; this would be a topic in which theoretical ecology again offers potential guidance (e.g., Chesson 2000, Siepielski and McPeek 2010) and would require more attention to spatial processes (e.g., Acevedo et al. 2015, Zelnik et al. 2015) and to temporal processes (such as seed persistence) than I have attempted here.

The ideas in Figures $2 \mathrm{~g}$ and $2 \mathrm{~h}$ are speculative. The nature and presence of other species and the optimal elevation for plant growth will play a role in determining how elevation and disturbance interact (see Fig. 4). The patterns of how species might persist in relation to the intensity and frequency of disturbance depend on whether the species are competitive dominants at any elevation or are effectively fugitives everywhere (Fig. 4a, b). The behavior will also depend on the elevation at which the most benign growth conditions occur (Fig. 4c, d). 
Fig. 4. Schematic illustration of vegetation elevation zones determined by an elevation-dependent temperature gradient and influenced by a range of disturbance frequencies or intensities (for explanation see Figs. 2 and 3). The behavior of species and communities will depend on whether the species involved are competitive dominants relative to the other species present, persist at some location on the gradient without disturbance (a), or are fugitives that require disturbance to persist anywhere (b). The dotted lines show the boundary of the fundamental niche and where species might be seen to occur; the colored patches show where species can sustain themselves in the presence of other community members. Species may occur outside these boundaries as nonviable sink populations or perhaps because of positive interactions among species. In some situations the cold of high elevation may constrain plant growth suggesting that increasing disturbance will lead to most species having greater resilience to disturbance at lower elevations (c). However, where temperatures are sufficiently high to constrain growth, increasing disturbance will lead to most species having greater resilience to disturbance at higher elevations (d). Again, I highlight the artificial nature of presenting disturbance on a single axis, and for an entire gradient. In reality, we can modify many aspects of disturbance and decide whether such changes are uniform or locally targeted.

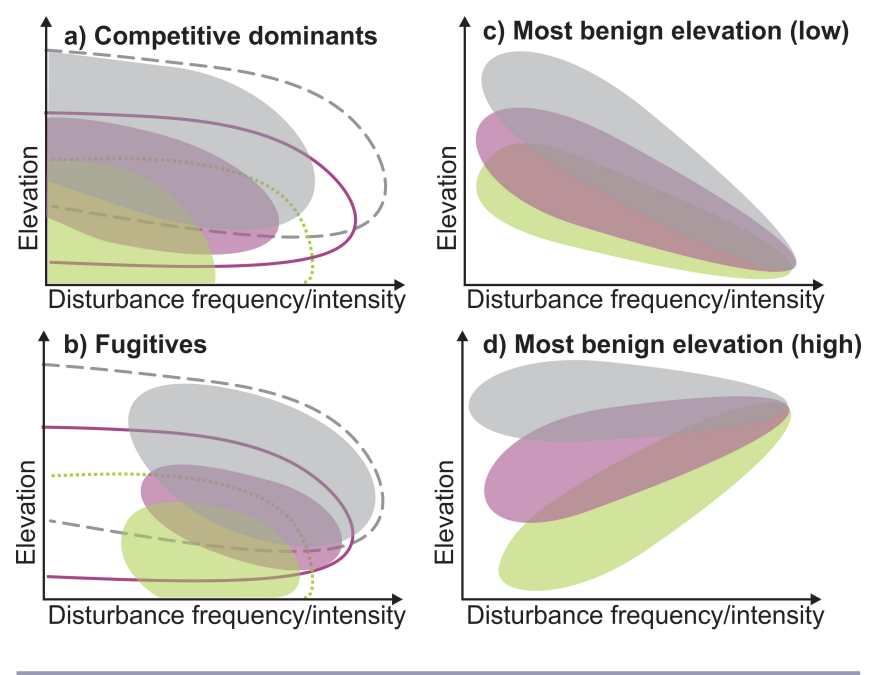

The principles outlined are not limited to temperatures or elevation gradients. They should apply whenever two or more species comprise a competitive hierarchy over any gradient. For example, we would expect a salt-tolerant species to occur more frequently in nonsaline habitats, surrounding a saline source population, when there is an optimal level and pattern of disturbance in the surrounding matrix. Understanding the nature of the realizable niche and the resulting determinants of range boundaries offers rich material for further investigations.

\section{Implications for conservation}

Disturbance is often discussed as a threat to species and the maintenance of conservation values (Turner 2010). Such concerns may blind us to its positive attributes, including that many, possibly most, species depend on disturbance for their persistence. Disturbance offers options for vegetation management: types, intensities, scales, frequencies, timing, and patterns of disturbance can be modified. Any given disturbance regime will favor some species over others and, unless it is already optimal, can be tuned or modified to better benefit targeted species.

Given the many variables involved, how can we devise a suitable intervention? Systematic approaches are possible. For example, viability analyses based on field-calibrated population models have been used to optimize frequencies and timing for burning, mowing, grazing, and sod cutting in herbaceous communities (briefly reviewed in Volis et al. 2005). Such analyses show that sod cutting every six to seven years is optimal for maintaining the rare marsh gentian Gentiana pneumonanthe in Dutch heathlands (Volis et al. 2005). However, given urgency and practical constraints, an adaptive management, learning-by-doing approach may often be appropriate (Keith et al. 2011, Moore et al. 2011). Choices should be informed by science and by local observations and concerns. Interventions need not involve only standard disturbance processes, but could involve activities such as protecting seed trees, creating firebreaks, weeding, and the targeted elimination of competitors. Goals will vary. We may want to identify the interventions that permit the lowest elevation in which a species can persist, or the lowest-cost options that facilitate population expansion at a given location. As long as we can judge among outcomes, some options (inaction included) will yield better results than others, and this can be clarified by local evaluations.

Disturbance can determine various aspects of competitive exclusion even in novel communities and conditions, but it is not a panacea. In practice, disturbance-based options would be additional to other aspects of conservation practice required to alleviate threats and would not replace assisted long-range dispersal and translocation where that is practical and desirable.

I have focused on plants, but the principles can be applied more broadly. This is clear when fauna are dependent on nonclimax vegetation and/or when their distributions are largely determined by intraspecific competition. An example of the first kind would be Australia's Mahogany glider Petaurus gracilis, which requires open woodlands to be maintained (e.g., by fire) in a region threatened by rainforest expansion (Jackson 1998). Examples of the second kind would include many sessile organisms (Sousa 1979) and perhaps mountain birds (Terborgh and Weske 1975, Jankowski et al. 2010).

I have focused on the prevention and slowing of species loss in a fixed location as conditions change. However, competition can influence other outcomes by having an impact on dispersal rates, on sites available for establishment, and various aspects of the biotic environment (Urban et al. 2012). There may also be situations in which connectivity among sites could and should be improved or in which the elimination of undesirable species becomes necessary. Disturbance management can thus have wider potential.

The use of disturbance involves risks. Any managed disturbance is additional to natural processes, and most natural processes cannot be readily controlled. A changing climate may intensify extreme weather events and increase associated uncertainties (Anderegg et al. 2013). All species have a limited tolerance for 
disturbance, and excessive disturbance is a threat to global biodiversity (Turner 2010). Increasing levels of disturbance can accelerate vegetation change (Loehle 1998, 2014), may create feedbacks that increase the likelihood of switching from one relatively stable ecological state to another (Beckage et al. 2009, Tredennick and Hanan 2015), and may permit the establishment of undesirable persistent vegetation (Roos et al. 2011, Douterlungne et al. 2013) or nonnative species (Moles et al. 2012, Jauni et al.2015). Our challenge is to identify and implement some form of more optimal disturbance regime; I am not suggesting we need more disturbance. Indeed often disturbance will need to be reduced. However, reducing disturbance also involves risk because vulnerable species may depend on the existing disturbance regime. In any case, some disturbance regimes will benefit targeted species more than others.

Some will be uncomfortable with using disturbance to generate and maintain unnatural ecological systems. Such proposals offend our instincts regarding the significance of pristine nature (Sheil and Meijaard 2010). I share this reaction. But if we allow climate change to advance so far as to threaten mass extinctions, we must accept the ethical dilemmas that this entails. In a rapidly changing climate, in which any reference to natural conditions has become an anachronism, we need to be open to all possible means to safeguard species. Any additional persistence of a species outside of its normal range increases the opportunities for adaptation, dispersal, or later intervention and reduces the risk of ultimate extinction. Disturbance is an underappreciated determinant of species distributions and persistence.

\section{CONCLUSIONS}

Disturbance provides a variety of means to modify a species' realized niche and thus influence species distributions. Although the relevant concepts are established, the broader implications appear neglected. Both theory and evidence indicate that disturbance processes permit many species to grow at lower elevations (higher temperature) than might occur otherwise. In a rapidly changing climate, any additional persistence of a species outside of its normal climatic range reduces extinction rates and increases opportunities for adaptation or interventions. The ability to extend the range and improve the likely persistence of selected species offers possible in situ alternatives to translocation and ex situ options. The right frequencies, scales, intensities, spatial configurations, and timings of the right forms of disturbance can slow and reduce extinctions. Such opportunities require evaluation.

Responses to this article can be read online at: http://www.ecologyandsociety.org/issues/responses. $\mathrm{php} / 7920$

\section{Acknowledgments:}

I thank David Burslem, Frans Bongers, Andy Gillison, Miriam van Heist, Markus Sydenham, Claire Miller, and unnamed reviewers for helpful comments on earlier drafts, and Craig Dremann, Koenraad van Meerbeek, and Klaus Gadow for help identifying relevant studies.

\section{LITERATURE CITED}

Acevedo, M. A., R. J. Fletcher, Jr., R. L. Tremblay, and E. J. Meléndez-Ackerman. 2015. Spatial asymmetries in connectivity influence colonization-extinction dynamics. Oecologia 179:415-424. http://dx.doi.org/10.1007/s00442-015-3361-z

Amarasekare, P. 2003. Competitive coexistence in spatially structured environments: a synthesis. Ecology Letters 6 (12):1109-1122. http://dx.doi.org/10.1046/j.1461-0248.2003.00530. $\underline{x}$

Anderegg, W. R. L., J. M. Kane, and L. D. L. Anderegg. 2013. Consequences of widespread tree mortality triggered by drought and temperature stress. Nature Climate Change 3(1):30-36. http:// dx.doi.org/10.1038/nclimate1635

Araújo, M. B., and A. T. Peterson. 2012. Uses and misuses of bioclimatic envelope modeling. Ecology 93(7):1527-1539. http:// dx.doi.org/10.1890/11-1930.1

Bakker, J. P. 1978. Changes in a salt-marsh vegetation as a result of grazing and mowing - a five-year study of permanent plots. Vegetatio 38(2):77-87. http://dx.doi.org/10.1007/bf00052038

Banitz, T., A. Huth, V. Grimm, and K. Johst. 2008. Clumped versus scattered: how does the spatial correlation of disturbance events affect biodiversity? Theoretical Ecology 1(4):231-240. http://dx.doi.org/10.1007/s12080-008-0023-3

Barbour, M. G. 1970. Is any angiosperm an obligate halophyte? American Midland Naturalist 84:105-120. http://dx.doi. $\underline{\operatorname{org} / 10.2307 / 2423730}$

Beckage, B., W. J. Platt, and L. J. Gross. 2009. Vegetation, fire and feedbacks: a disturbance-mediated model of savannas. American Naturalist 174(6):805-818. http://dx.doi.org/10.1086/648458

Bell, D. T. 2001. Ecological response syndromes in the flora of southwestern Western Australia: fire resprouters versus reseeders. Botanical Review 67(4):417-440. http://dx.doi.org/10.1007/ $\underline{\mathrm{bf0} 2857891}$

Belyea, L. R., and J. Lancaster. 1999. Assembly rules within a contingent ecology. Oikos 86(3):402-416. http://dx.doi. org/10.2307/3546646

Birks, H. J. B., and K. J. Willis. 2008. Alpines, trees, and refugia in Europe. Plant Ecology and Diversity 1(2):147-160. http://dx. doi.org/10.1080/17550870802349146

Bobbink, R., and J. H. Willems. 1993. Restoration management of abandoned chalk grassland in the Netherlands. Biodiversity and Conservation 2(6):616-626. http://dx.doi.org/10.1007/ $\underline{\text { bf00051962 }}$

Bronstein, J. L. 1994. Conditional outcomes in mutualistic interactions. Trends in Ecology and Evolution 9(6):214-217. http:// dx.doi.org/10.1016/0169-5347(94)90246-1

Brooker, R. W., F. T. Maestre, R. M. Callaway, C. L. Lortie, L. A. Cavieres, G. Kunstler, P. Liancourt, K. Tielbörger, J. M. J. Travis, F. Anthelme, C. Armas, L. Coll, E. Corcket, S. Delzon, E. Forey, Z. Kikvidze, J. Olofsson, F. Pugnaire, C. L. Quiroz, P. Saccone, K. Schiffers, M. Seifan, B. Touzard, and R. Michalet. 2008. Facilitation in plant communities: the past, the present, and the future. Journal of Ecology 96(1):18-34. http://dx.doi. org/10.1111/j.1365-2745.2007.01295.x 
Brown, C. D., and M. Vellend. 2014. Non-climatic constraints on upper elevational plant range expansion under climate change. Proceedings of the Royal Society B: Biological Sciences 281 (1794):20141779. http://dx.doi.org/10.1098/rspb.2014.1779

Budowski, G. 1965. Distribution of tropical American rain forest species in the light of successional processes. Turrialba 15 (1):40-42.

Cabral, J. S., and H. Kreft. 2012. Linking ecological niche, community ecology and biogeography: insights from a mechanistic niche model. Journal of Biogeography 39 (12):2212-2224. http://dx.doi.org/10.1111/jbi.12010

Cahill, A. E., M. E. Aiello-Lammens, M. C. Fisher-Reid, X. Hua, C. J. Karanewsky, H. Y. Ryu, G. C. Sbeglia, F. Spagnolo, J. B. Waldron, O. Warsi, and J. J. Wiens. 2013. How does climate change cause extinction? Proceedings of the Royal Society B: Biological Sciences 280(1750):20121890. http://dx.doi.org/10.1098/rspb.2012.1890

Chesson, P. 2000. Mechanisms of maintenance of species diversity. Annual Review of Ecology, Evolution, and Systematics 31:343-366. http://dx.doi.org/10.1146/annurev.ecolsys.31.1.343

Chesson, P., and N. Huntly. 1997. The roles of harsh and fluctuating conditions in the dynamics of ecological communities. American Naturalist 150(5):519-553. http://dx.doi.org/10.1086/286080

Chiarucci, A., M. B. Araújo, G. Decocq, C. Beierkuhnlein, and J. M. Fernández-Palacios. 2010. The concept of potential natural vegetation: an epitaph? Journal of Vegetation Science 21 (6):1172-1178. http://dx.doi.org/10.1111/j.1654-1103.2010.01218. $\underline{x}$

Clark, J. S. 1996. Testing disturbance theory with long-term data: alternative life-history solutions to the distribution of events. American Naturalist 148:976-996. http://dx.doi.org/10.1086/285967

Cleavitt, N. 2004. Comparative ecology of a lowland and a subalpine species of Mnium in the northern Rocky Mountains. Plant Ecology 174(2):205-216. http://dx.doi.org/10.1023/b: vege.0000049099.11785.ba

Collins, S. L., A. K. Knapp, J. M. Briggs, J. M. Blair, and E. M. Steinauer. 1998. Modulation of diversity by grazing and mowing in native tallgrass prairie. Science 280(5364):745-747. http://dx. doi.org/10.1126/science.280.5364.745

Colwell, R. K., G. Brehm, C. L. Cardelús, A. C. Gilman, and J. T. Longino. 2008. Global warming, elevational range shifts, and lowland biotic attrition in the wet tropics. Science 322 (5899):258-261. http://dx.doi.org/10.1126/science.1162547

Colwell, R. K., and E. R. Fuentes. 1975. Experimental studies of the niche. Annual Review of Ecology and Systematics 6:281-310. http://dx.doi.org/10.1146/annurev.es.06.110175.001433

Connell, J. H. 1978. Diversity in tropical rain forests and coral reefs. Science 199(4335):1302-1310. http://dx.doi.org/10.1126/ science.199.4335.1302

Corlett, R. T., and D. A. Westcott. 2013. Will plant movements keep up with climate change? Trends in Ecology and Evolution 28 (8):482-488. http://dx.doi.org/10.1016/j.tree.2013.04.003

Crimmins, S. M., S. Z. Dobrowski, J. A. Greenberg, J. T. Abatzoglou, and A. R. Mynsberge. 2011. Changes in climatic water balance drive downhill shifts in plant species' optimum elevations. Science 331(6015):324-327. http://dx.doi.org/10.1126/ science. 1199040

Daniau, A.-L., S. Harrison, and P. Bartlein. 2010. Fire regimes during the last glacial. Quaternary Science Reviews 29 (21):2918-2930. http://dx.doi.org/10.1016/j.quascirev.2009.11.008

Davis, A. J., L. S. Jenkinson, J. H. Lawton, B. Shorrocks, and S. Wood. 1998. Making mistakes when predicting shifts in species range in response to global warming. Nature 391(6669):783-786. http://dx.doi.org/10.1038/35842

Douterlungne, D., E. Thomas, and S. I. Levy-Tacher. 2013. Fastgrowing pioneer tree stands as a rapid and effective strategy for bracken elimination in the Neotropics. Journal of Applied Ecology 50(5):1257-1265. http://dx.doi.org/10.1111/1365-2664.12077

Everham, E. M., and N. V. L. Brokaw. 1996. Forest damage and recovery from catastrophic wind. Botanical Review 62(2):113-185. http://dx.doi.org/10.1007/bf02857920

Fordham, D. A., H. Resit Akçakaya, M. B. Araújo, J. Elith, D. A. Keith, R. Pearson, T. D. Auld, C. Mellin, J. W. Morgan, T. J. Regan, M. Tozer, M. J. Watts, M. White, B. A. Wintle, C. Yates, and B. W. Brook. 2012. Plant extinction risk under climate change: are forecast range shifts alone a good indicator of species vulnerability to global warming? Global Change Biology 18 (4):1357-1371. http://dx.doi.org/10.1111/j.1365-2486.2011.02614. $\underline{x}$

Fox, J. W. 2013. The intermediate disturbance hypothesis should be abandoned. Trends in Ecology and Evolution 28(2):86-92. http://dx.doi.org/10.1016/j.tree.2012.08.014

Gehrke, B., and H. P. Linder. 2009. The scramble for Africa: pantemperate elements on the African high mountains. Proceedings of the Royal Society B: Biological Sciences 276(1667):2657-2665. http://dx.doi.org/10.1098/rspb.2009.0334

Gennaretti, F., D. Arseneault, and Y. Bégin. 2014. Millennial disturbance-driven forest stand dynamics in the Eastern Canadian taiga reconstructed from subfossil logs. Journal of Ecology 102(6):1612-1622. http://dx.doi.org/10.1111/1365-2745.12315

Gilbert, A. A., and L. H. Fraser. 2013. Effects of salinity and clipping on biomass and competition between a halophyte and a glycophyte. Plant Ecology 214(3):433-442. http://dx.doi. org/10.1007/s11258-013-0180-3

Grubb, P. J. 1977. The maintenance of species-richness in plant communities: the importance of the regeneration niche. Biological Reviews 52(1):107-145. http://dx.doi.org/10.1111/j.1469-185x.1977. $\underline{\text { tb01347.x }}$

Grytnes, J. A., J. Kapfer, G. Jurasinski, H. H. Birks, H. Henriksen, K. Klanderud, A. Odland, M. Ohlson, S. Wipf, and H. J. B. Birks. 2014. Identifying the driving factors behind observed elevational range shifts on European mountains. Global Ecology and Biogeography 23(8):876-884. http://dx.doi.org/10.1111/geb.12170

Guisan, A., and C. Rahbek. 2011. SESAM - a new framework integrating macroecological and species distribution models for predicting spatio-temporal patterns of species assemblages. Journal of Biogeography 38(8):1433-1444. http://dx.doi. org/10.1111/j.1365-2699.2011.02550.x 
Guisan, A., and W. Thuiller. 2005. Predicting species distribution: offering more than simple habitat models. Ecology Letters 8 (9):993-1009. http://dx.doi.org/10.1111/j.1461-0248.2005.00792. $\underline{x}$

Hamilton, A. C., and R. A. Perrott. 1981. A study of altitudinal zonation in the montane forest belt of Mt. Elgon, Kenya/Uganda. Vegetatio 45(2):107-125. http://dx.doi.org/10.1007/BF00119220

Hargreaves, A. L., K. E. Samis, and C. G. Eckert. 2014. Are species' range limits simply niche limits writ large? A review of transplant experiments beyond the range. American Naturalist 183(2):157-173. http://dx.doi.org/10.1086/674525

Harrison, S., H. Cornell, and K. A. Moore. 2010. Spatial niches and coexistence: testing theory with tarweeds. Ecology 91 (7):2141-2150. http://dx.doi.org/10.1890/09-0742.1

He, T., B. B. Lamont, and K. S. Downes. 2011. Banksia born to burn. New Phytologist 191(1):184-196. http://dx.doi.org/10.1111/ j.1469-8137.2011.03663.x

Hemp, A. 2006. Vegetation of Kilimanjaro: hidden endemics and missing bamboo. African Journal of Ecology 44(3):305-328. http:// dx.doi.org/10.1111/j.1365-2028.2006.00679.x

Hewett, D. G. 1985. Grazing and mowing as management tools on dunes. Vegetatio 62(1):441-447. http://dx.doi.org/10.1007/ $\underline{\mathrm{BF} 00044772}$

HilleRisLambers, J., M. A. Harsch, A. K. Ettinger, K. R. Ford, and E. J. Theobald. 2013. How will biotic interactions influence climate change-induced range shifts? Annals of the New York Academy of Sciences 1297(1):112-125. http://dx.doi.org/10.1111/ nyas. 12182

Hoegh-Guldberg, O., L. Hughes, S. McIntyre, D. B. Lindenmayer, C. Parmesan, H. P. Possingham, and C. D. Thomas. 2008. Assisted colonization and rapid climate change. Science 321 (5887):345-346. http://dx.doi.org/10.1126/science.1157897

Huey, R. B., M. R. Kearney, A. Krockenberger, J. A. M. Holtum, M. Jess, and S. E. Williams. 2012. Predicting organismal vulnerability to climate warming: roles of behaviour, physiology and adaptation. Philosophical Transactions of the Royal Society B: Biological Sciences 367(1596):1665-1679. http://dx.doi. org/10.1098/rstb.2012.0005

Huston, M. A. 2014. Disturbance, productivity, and species diversity: empiricism vs. logic in ecological theory. Ecology 95 (9):2382-2396. http://dx.doi.org/10.1890/13-1397.1

Jackson, S. M. 1998. Foraging ecology, behaviour and management of the mahogany glider Petaurus gracilis. Dissertation. James Cook University, Townsville City, Queensland, Australia. [online] URL: http://researchonline.jcu.edu.au/17428/

Jankowski, J. E., S. K. Robinson, and D. J. Levey. 2010. Squeezed at the top: interspecific aggression may constrain elevational ranges in tropical birds. Ecology 91(7):1877-1884. http://dx.doi. org/10.1890/09-2063.1

Jauni, M., S. Gripenberg, and S. Ramula. 2015. Non-native plant species benefit from disturbance: a meta-analysis. Oikos 124 (2):122-129. http://dx.doi.org/10.1111/oik.01416

Johns, R. J. 1986. The instability of the tropical ecosystem in New Guinea. Blumea 31(2):341-371.
Jump, A. S., C. Mátyás, and J. Peñuelas. 2009. The altitude-forlatitude disparity in the range retractions of woody species. Trends in Ecology and Evolution 24(12):694-701. http://dx.doi. org/10.1016/j.tree.2009.06.007

Kappelle, M., P. A. F. Kennis, and R. A. J. de Vries. 1995. Changes in diversity along a successional gradient in a Costa Rican upper montane Quercus forest. Biodiversity and Conservation 4(1):10-34. http://dx.doi.org/10.1007/bf00115312

Keddy, P. A., and B. Shipley. 1989. Competitive hierarchies in herbaceous plant communities. Oikos 54(2):234-241. http://dx. doi.org/10.2307/3565272

Keeley, J. E., J. G. Pausas, P. W. Rundel, W. J. Bond, and R. A. Bradstock. 2011. Fire as an evolutionary pressure shaping plant traits. Trends in Plant Science 16(8):406-411. http://dx.doi. org/10.1016/j.tplants.2011.04.002

Keith, D. A., T. G. Martin, E. McDonald-Madden, and C. Walters. 2011. Uncertainty and adaptive management for biodiversity conservation. Biological Conservation 144(4):1175-1178. http://dx.doi.org/10.1016/j.biocon.2010.11.022

Körner, C. 1998. A re-assessment of high elevation treeline positions and their explanation. Oecologia 115(4):445-459. http:// dx.doi.org/10.1007/s004420050540

Kubisch, A., R. D. Holt, H.-J. Poethke, and E. A. Fronhofer. 2014. Where am I and why? Synthesizing range biology and the ecoevolutionary dynamics of dispersal. Oikos 123(1):5-22. http://dx. doi.org/10.1111/j.1600-0706.2013.00706.x

Kuuluvainen, T. 2009. Forest management and biodiversity conservation based on natural ecosystem dynamics in northern Europe: the complexity challenge. Ambio 38(6):309-315. http:// dx.doi.org/10.1579/08-a-490.1

Levine, J. M., and M. Rees. 2002. Coexistence and relative abundance in annual plant assemblages: the roles of competition and colonization. American Naturalist 160(4):452-467. http://dx. doi.org/10.1086/342073

Loarie, S. R., P. B. Duffy, H. Hamilton, G. P. Asner, C. B. Field, and D. D. Ackerly. 2009. The velocity of climate change. Nature 462(7276):1052-1055. http://dx.doi.org/10.1038/nature08649

Loehle, C. 1998. Height growth rate tradeoffs determine northern and southern range limits for trees. Journal of Biogeography 25 (4):735-742. http://dx.doi.org/10.1046/j.1365-2699.1998.2540735. $\underline{\mathrm{X}}$

Loehle, C. 2014. Climate change is unlikely to cause a biodiversity crisis: evidence from northern latitude tree responses to warming. Energy and Environment 25(1):147-154. http://dx.doi. org/10.1260/0958-305x.25.1.147

Long, J. N. 2009. Emulating natural disturbance regimes as a basis for forest management: a North American view. Forest Ecology and Management 257(9):1868-1873. http://dx.doi.org/10.1016/j. foreco.2008.12.019

Lovett, J. C. 1996. Elevational and latitudinal changes in tree associations and diversity in the Eastern Arc mountains of Tanzania. Journal of Tropical Ecology 12(5):629-650. http://dx. doi.org/10.1017/s0266467400009846 
Maestri, E., M. Marmiroli, G. Visioli, and N. Marmiroli. 2010. Metal tolerance and hyperaccumulation: costs and trade-offs between traits and environment. Environmental and Experimental Botany 68(1):1-13. http://dx.doi.org/10.1016/j.envexpbot.2009.10.011

Malanson, G. P. 1984. Intensity as a third factor of disturbance regime and its effect on species diversity. Oikos 43:411-413. http:// dx.doi.org/10.2307/3544165

Mangan, S. A., S. A. Schnitzer, E. A. Herre, K. M. L. Mack, M. C. Valencia, E. I. Sanchez, and J. D. Bever. 2010. Negative plantsoil feedback predicts tree-species relative abundance in a tropical forest. Nature 466(7307):752-755. http://dx.doi.org/10.1038/ $\underline{\text { nature } 09273}$

Martorell, C., and R. P. Freckleton. 2014. Testing the roles of competition, facilitation and stochasticity on community structure in a species-rich assemblage. Journal of Ecology 102 (1):74-85. http://dx.doi.org/10.1111/1365-2745.12173

Mawdsley, J. R., R. O’Malley, and D. S. Ojima. 2009. A review of climate-change adaptation strategies for wildlife management and biodiversity conservation. Conservation Biology 23 (5):1080-1089. http://dx.doi.org/10.1111/j.1523-1739.2009.01264. $\underline{\mathrm{X}}$

McCain, C. M., and R. K. Colwell. 2011. Assessing the threat to montane biodiversity from discordant shifts in temperature and precipitation in a changing climate. Ecology Letters 14 (12):1236-1245. http://dx.doi.org/10.1111/j.1461-0248.2011.01695. $\underline{\mathrm{x}}$

McCain, C. M., and J.-A. Grytnes. 2001. Elevational gradients in species richness. eLS. John Wiley and Sons, Ltd., Chichester, UK. http://dx.doi.org/10.1002/9780470015902.a0022548

McGill, B. J. 2012. Trees are rarely most abundant where they grow best. Journal of Plant Ecology 5(1):46-51. http://dx.doi. org/10.1093/jpe/rtr036

Menke, J. W. 1992. Grazing and fire management for native perennial grass restoration in California grasslands. Fremontia 20 (2):22-25.

Miller, A. D., S. H. Roxburgh, and K. Shea. 2011. How frequency and intensity shape diversity-disturbance relationships. Proceedings of the National Academy of Sciences 108 (14):5643-5648. http://dx.doi.org/10.1073/pnas.1018594108

Miller, T. E. 1982. Community diversity and interactions between the size and frequency of disturbance. American Naturalist 120:533-536. http://dx.doi.org/10.1086/284009

Minteer, B. A., and J. P. Collins. 2010. Move it or lose it? The ecological ethics of relocating species under climate change. Ecological Applications 20(7):1801-1804. http://dx.doi. org/10.1890/10-0318.1

Moles, A. T., H. Flores-Moreno, S. P. Bonser, D. I. Warton, A. Helm, L. Warman, D. J. Eldridge, E. Jurado, F. A. Hemmings, P. B. Reich, J. Cavender-Bares, E. W. Seabloom, M. M. Mayfield, D. Sheil, J. C. Djietror, P. L. Peri, L. Enrico, M. R. Cabido, S. A. Setterfield, C. E. R. Lehmann, and F. J. Thomson. 2012. Invasions: the trail behind, the path ahead, and a test of a disturbing idea. Journal of Ecology 100(1):116-127. http://dx.doi. org/10.1111/j.1365-2745.2011.01915.X
Monty, M. L. F., F. B. V. Florens, and C. Baider. 2013. Invasive alien plants elicit reduced production of flowers and fruits in various native forest species on the tropical island of Mauritius (Mascarenes, Indian Ocean). Tropical Conservation Science 6 (1):35-49. [online] URL: http://tropicalconservationscience. mongabay.com/content/v6/TCS-2013_Vol 6(1) 35-49_Monty_et_al. pdf

Moore, C. T., C. J. Fonnesbeck, K. Shea, K. J. Lah, P. M. McKenzie, L. C. Ball, M. C. Runge, and H. M. Alexander. 2011. An adaptive decision framework for the conservation of a threatened plant. Journal of Fish and Wildlife Management 2 (2):247-261. http://dx.doi.org/10.3996/012011-jfwm-007

Morley, R. J. 2000. Origin and evolution of tropical rain forests. John Wiley and Sons, Ltd., Chichester, UK.

Nuttle, T., A. A. Royo, M. B. Adams, and W. P. Carson. 2013. Historic disturbance regimes promote tree diversity only under low browsing regimes in eastern deciduous forest. Ecological Monographs 83(1):3-17. http://dx.doi.org/10.1890/11-2263.1

Ohsawa, M. 1995. Latitudinal comparison of altitudinal changes in forest structure, leaf-type, and species richness in humid monsoon Asia. Vegetatio 121(1):3-10. http://dx.doi.org/10.1007/ BF00044667

Olago, D. O. 2001. Vegetation changes over palaeo-time scales in Africa. Climate Research 17(2):105-121. http://dx.doi.org/10.3354/ $\underline{\mathrm{cr} 017105}$

Oldeman, R. A. A. 1990. Forests: elements of silvology. SpringerVerlag, Berlin, Germany. http://dx.doi.org/10.1007/978-3-642-75211-7

Olivera, M. M., J. F. Duivenvoorden, and H. Hooghiemstra. 2009. Pollen rain and pollen representation across a forest-páramo ecotone in northern Ecuador. Review of Palaeobotany and Palynology 157(3-4):285-300. http://dx.doi.org/10.1016/j. revpalbo.2009.05.008

Palmer, M. W. 1994. Variation in species richness: towards a unification of hypotheses. Folia Geobotanica et Phytotaxonomica 29(4):511-530. http://dx.doi.org/10.1007/bf02883148

Parr, C. L., and A. N. Andersen. 2006. Patch mosaic burning for biodiversity conservation: a critique of the pyrodiversity paradigm. Conservation Biology 20(6):1610-1619. http://dx.doi. org/10.1111/j.1523-1739.2006.00492.x

Perera, A. H., and W. Cui. 2010. Emulating natural disturbances as a forest management goal: lessons from fire regime simulations. Forest Ecology and Management 259(7):1328-1337. http://dx.doi. org/10.1016/j.foreco.2009.03.018

Petermann, J. S., A. J. F. Fergus, L. A. Turnbull, and B. Schmid. 2008. Janzen-Connell effects are widespread and strong enough to maintain diversity in grasslands. Ecology 89(9):2399-2406. http://dx.doi.org/10.1890/07-2056.1

Pickett, S. T. A., S. L. Collins, and J. J. Armesto. 1987. A hierarchical consideration of causes and mechanisms of succession. Vegetatio 69(1):109-114. http://dx.doi.org/10.1007/ $\underline{\mathrm{BF} 00038691}$

Pigott, C. D., and S. M. Walters. 1954. On the interpretation of the discontinuous distributions shown by certain British species 
of open habitats. Journal of Ecology 42:95-116. http://dx.doi. org/10.2307/2256981

Preston, J. C., and S. R. Sandve. 2013. Adaptation to seasonality and the winter freeze. Frontiers in Plant Science 4:167. http://dx. doi.org/10.3389/fpls.2013.00167

Pulliam, H. R. 2000. On the relationship between niche and distribution. Ecology Letters 3(4):349-361. http://dx.doi. org/10.1046/j.1461-0248.2000.00143.x

Ricciardi, A., and D. Simberloff. 2009. Assisted colonization is not a viable conservation strategy. Trends in Ecology and Evolution 24(5):248-253. http://dx.doi.org/10.1016/j.tree.2008.12.006

Ricklefs, R. E. 2005. Historical and ecological dimensions of global patterns in plant diversity. Biologiske Skrifter 55:583-603. [online] URL: http://www.umsl.edu/ ricklefsr/Reprints/R2005b. pdf

Roos, K., H. G. Rödel, and E. Beck. 2011. Short- and long-term effects of weed control on pastures infested with Pteridium arachnoideum and an attempt to regenerate abandoned pastures in South Ecuador. Weed Research 51(2):165-176. http://dx.doi. org/10.1111/j.1365-3180.2010.00833.x

Rozendaal, D. M. A., R. J. W. Brienen, C. C. Soliz-Gamboa, and P. A. Zuidema. 2010. Tropical tree rings reveal preferential survival of fast-growing juveniles and increased juvenile growth rates over time. New Phytologist 185(3):759-769. http://dx.doi. org/10.1111/j.1469-8137.2009.03109.x

Sassen, M., and D. Sheil. 2013. Human impacts on forest structure and species richness on the edges of a protected mountain forest in Uganda. Forest Ecology and Management 307:206-218. http:// dx.doi.org/10.1016/j.foreco.2013.07.010

Serrano, H. C., C. Antunes, M. J. Pinto, C. Máguas, M. A. Martins-Loução, and C. Branquinho. 2015. The ecological performance of metallophyte plants thriving in geochemical islands is explained by the Inclusive Niche Hypothesis. Journal of Plant Ecology 8(1):41-50. http://dx.doi.org/10.1093/jpe/rtu007

Sexton, J. P., P. J. McIntyre, A. L. Angert, and K. J. Rice. 2009. Evolution and ecology of species range limits. Annual Review of Ecology, Evolution, and Systematics 40(1):415-436. http://dx.doi. org/10.1146/annurev.ecolsys.110308.120317

Shea, K., S. H. Roxburgh, and E. S. J. Rauschert. 2004. Moving from pattern to process: coexistence mechanisms under intermediate disturbance regimes. Ecology Letters 7(6):491-508. http://dx.doi.org/10.1111/j.1461-0248.2004.00600.x

Sheil, D. 1999. Tropical forest diversity, environmental change and species augmentation: after the intermediate disturbance hypothesis. Journal of Vegetation Science 10(6):851-860. http:// dx.doi.org/10.2307/3237310

Sheil, D., and D. F. R. P. Burslem. 2003. Disturbing hypotheses in tropical forests. Trends in Ecology and Evolution 18(1):18-26. http://dx.doi.org/10.1016/s0169-5347(02)00005-8

Sheil, D., and D. F. R. P. Burslem. 2013. Defining and defending Connell's intermediate disturbance hypothesis: a response to Fox. Trends in Ecology and Evolution 28(10):571-572. http://dx.doi. org/10.1016/j.tree.2013.07.006
Sheil, D., and E. Meijaard. 2010. Purity and prejudice: deluding ourselves about biodiversity conservation. Biotropica 42 (5):566-568. http://dx.doi.org/10.1111/j.1744-7429.2010.00687.x

Sheil, D., and A. Salim. 2004. Forest tree persistence, elephants, and stem scars. Biotropica 36(4):505-521. http://dx.doi. org/10.1111/j.1744-7429.2004.tb00346.x

Siepielski, A. M., and M. A. McPeek. 2010. On the evidence for species coexistence: a critique of the coexistence program. Ecology 91(11):3153-3164. http://dx.doi.org/10.1890/10-0154.1

Silvertown, J. 2004. Plant coexistence and the niche. Trends in Ecology and Evolution 19(11):605-611. http://dx.doi.org/10.1016/ j.tree.2004.09.003

Silvertown, J., and P. Dale. 1991. Competitive hierarchies and the structure of herbaceous plant communities. Oikos 61:441-444. http://dx.doi.org/10.2307/3545253

Sinervo, B., F. Méndez-De-La-Cruz, D. B. Miles, B. Heulin, E. Bastiaans, M. Villagrán-Santa Cruz, R. Lara-Resendiz, N. Martínez-Méndez, M. L. Calderón-Espinosa, R. N. MezaLázaro, H. Gadsden, L. J. Avila, M. Morando, I. J. De la Riva, P. V. Sepulveda, C. F. D. Rocha, N. Ibargüengoytía, C. Aguilar Puntriano, M. Massot, V. Lepetz, T. A. Oksanen, D. G. Chapple, A. M. Bauer, W. R. Branch, J. Clobert, and J. W. Sites, Jr. 2010. Erosion of lizard diversity by climate change and altered thermal niches. Science 328(5980):894-899. http://dx.doi.org/10.1126/ $\underline{\text { science. } 1184695}$

Smith, A. P., and T. P. Young. 1987. Tropical alpine plant ecology. Annual Review of Ecology and Systematics 18:137-158. http://dx. doi.org/10.1146/annurev.es.18.110187.001033

Smith, T., and M. Huston. 1990. A theory of the spatial and temporal dynamics of plant communities. Pages 49-69 in $\mathrm{G}$. Grabherr, L. Mucina, M. B. Dale, and C. J. F. ter Braak, editors. Progress in theoretical vegetation science. Springer, Amsterdam, Netherlands.

Soberón, J. 2007. Grinnellian and Eltonian niches and geographic distributions of species. Ecology Letters 10(12):1115-1123. http:// dx.doi.org/10.1111/j.1461-0248.2007.01107.x

Somero, G. N. 2011. Comparative physiology: a "crystal ball” for predicting consequences of global change. American Journal of Physiology-Regulatory, Integrative and Comparative Physiology 301(1):R1-R14. http://dx.doi.org/10.1152/ajpregu.00719.2010

Sousa, W. P. 1979. Experimental investigations of disturbance and ecological succession in a rocky intertidal algal community. Ecological Monographs 49(3):227-254. http://dx.doi.org/10.2307/1942484

Spear, D., and S. L. Chown. 2009. Non-indigenous ungulates as a threat to biodiversity. Journal of Zoology 279(1):1-17. http://dx. doi.org/10.1111/j.1469-7998.2009.00604.X

Stanton-Geddes, J., P. Tiffin, and R. G. Shaw. 2012. Role of climate and competitors in limiting fitness across range edges of an annual plant. Ecology 93(7):1604-1613. http://dx.doi. org/10.1890/11-1701.1

Stebbins, G. L. 1981. Coevolution of grasses and herbivores. Annals of the Missouri Botanical Garden 68(1):75-86. http://dx. doi.org/10.2307/2398811 
Supp, S. R., and S. K. M. Ernest. 2014. Species-level and community-level responses to disturbance: a cross-community analysis. Ecology 95(7):1717-1723. http://dx.doi.org/10.1890/13-2250.1

Svenning, J.-C., D. Gravel, R. D. Holt, F. M. Schurr, W. Thuiller, T. Münkemüller, K. H. Schiffers, S. Dullinger, T. C. Edwards, Jr., T. Hickler, S. I. Higgins, J. E. M. S. Nabel, J. Pagel, and S. Normand. 2014. The influence of interspecific interactions on species range expansion rates. Ecography 37:1198-1209. http://dx. doi.org/10.1111/j.1600-0587.2013.00574.x

Terborgh, J., and J. S. Weske. 1975. The role of competition in the distribution of Andean birds. Ecology 56(3):562-576. http://dx. doi.org/10.2307/1935491

Thomas, C. D., A. M. A. Franco, and J. K. Hill. 2006. Range retractions and extinction in the face of climate warming. Trends in Ecology and Evolution 21(8):415-416. http://dx.doi. org/10.1016/j.tree.2006.05.012

Tilman, D. 1990. Constraints and tradeoffs - toward a predictive theory of competition and succession. Oikos 58(1):3-15. http:// dx.doi.org/10.2307/3565355

Tormo, J., B. Moreira, and J. G. Pausas. 2014. Field evidence of smoke-stimulated seedling emergence and establishment in Mediterranean Basin flora. Journal of Vegetation Science 25 (3):771-777. http://dx.doi.org/10.1111/jvs. 12120

Tredennick, A. T., and N. P. Hanan. 2015. Effects of tree harvest on the stable-state dynamics of savanna and forest. American Naturalist 185(5):E153-E165. http://dx.doi.org/10.1086/680475

Trivedi, M. R., P. M. Berry, M. D. Morecroft, and T. P. Dawson. 2008. Spatial scale affects bioclimate model projections of climate change impacts on mountain plants. Global Change Biology 14 (5):1089-1103. http://dx.doi.org/10.1111/j.1365-2486.2008.01553. $\underline{\mathrm{x}}$

Turner, M. G. 2010. Disturbance and landscape dynamics in a changing world. Ecology 91:2833-2849. http://dx.doi. org/10.1890/10-0097.1

Urban, M. C., J. J. Tewksbury, and K. S. Sheldon. 2012. On a collision course: competition and dispersal differences create noanalogue communities and cause extinctions during climate change. Proceedings of the Royal Society B: Biological Sciences 279(1735):2072-2080. http://dx.doi.org/10.1098/rspb.2011.2367

van Nieuwstadt, M. G. L., and D. Sheil. 2005. Drought, fire and tree survival in a Borneo rain forest, East Kalimantan, Indonesia. Journal of Ecology 93(1):191-201. http://dx.doi.org/10.1111/ j.1365-2745.2004.00954.x

van Steenis, C. G. G. J. 1958. Rejuvenation as a factor in judging the status of vegetation types: the biological nomad theory. Pages 212-218 in Study of tropical vegetation: proceedings of the Kandy Symposium. UNESCO, Paris, France. [online] URL: http:// unesdoc. unesco.org/Ulis/cgi-bin/ulis.pl? catno $=19485 \&$ set $=49$ B99AC2 $3 \quad 7 \& g p=1 \& l i n=1$

Vandermeer, J. H. 1972. Niche theory. Annual Review of Ecology and Systematics 3:107-132. http://dx.doi.org/10.1146/annurev. es.03.110172.000543
Violle, C., Z. Pu, and L. Jiang. 2010. Experimental demonstration of the importance of competition under disturbance. Proceedings of the National Academy of Sciences 107(29):12925-12929. http:// dx.doi.org/10.1073/pnas.1000699107

Virtanen, R., M. Luoto, T. Rämä, K. Mikkola, J. Hjort, J. A. Grytnes, and H. J. B. Birks. 2010. Recent vegetation changes at the high-latitude tree line ecotone are controlled by geomorphological disturbance, productivity and diversity. Global Ecology and Biogeography 19(6):810-821. http://dx.doi. org/10.1111/j.1466-8238.2010.00570.x

Volis, S., G. Bohrer, G. Oostermeijer, and P. Van Tienderen. 2005. Regional consequences of local population demography and genetics in relation to habitat management in Gentiana pneumonanthe. Conservation Biology 19(2):357-367. http://dx.doi. org/10.1111/j.1523-1739.2005.00564.X

Warner, R. R., and P. L. Chesson. 1985. Coexistence mediated by recruitment fluctuations: a field guide to the storage effect. American Naturalist 235(6):769-787. http://dx.doi.org/10.1086/284379

Warren, R., J. VanDerWal, J. Price, J. A. Welbergen, I. Atkinson, J. Ramirez-Villegas, T. J. Osborn, A. Jarvis, L. P. Shoo, S. E. Williams, and J. Lowe. 2013. Quantifying the benefit of early climate change mitigation in avoiding biodiversity loss. Nature Climate Change 3:678-682. http://dx.doi.org/10.1038/nclimate1887

Webb, E. L., M. Bult, S. Fa'aumu, R. C. Webb, A. Tualaulelei, and L. R. Carrasco. 2014. Factors affecting tropical tree damage and survival after catastrophic wind disturbance. Biotropica 46 (1):32-41. http://dx.doi.org/10.1111/btp.12067

Weiner, J. 1990. Asymmetric competition in plant populations. Trends in Ecology and Evolution 5(11):360-364. http://dx.doi. org/10.1016/0169-5347(90)90095-u

White, S. 2013. Grass páramo as hunter-gatherer landscape. Holocene 23:898-915. http://dx.doi.org/10.1177/0959683612471987

White, P. S., and A. Jentsch. 2001. The search for generality in studies of disturbance and ecosystem dynamics. Pages 399-450 in Progress in Botany. Springer, Berlin, Germany. http://dx.doi. org/10.1007/978-3-642-56849-7_17

Wiens, J. A., D. Stralberg, D. Jongsomjit, C. A. Howell, and M. A. Snyder. 2009. Niches, models, and climate change: assessing the assumptions and uncertainties. Proceedings of the National Academy of Sciences 106(Supplement 2):19729-19736. http://dx. doi.org/10.1073/pnas.0901639106

Wilson, J. B. 1994. The 'intermediate disturbance hypothesis' of species coexistence is based on patch dynamics. New Zealand Journal of Ecology 18(2):176-181. [online] URL: http:// newzealandecology.org/nzje/1957.pdf

Wisheu, I. C. 1998. How organisms partition habitats: different types of community organization can produce identical patterns. Oikos 83(2):246-258. http://dx.doi.org/10.2307/3546836

Wisz, M. S., J. Pottier, W. D. Kissling, L. Pellissier, J. Lenoir, C. F. Damgaard, C. F. Dormann, M. C. Forchhammer, J.-A. Grytnes, A. Guisan, R. K. Heikkinen, T. T. Høye, I. Kühn, M. Luoto, L. Maiorano, M.-C. Nilsson, S. Normand, E. Öckinger, N. M. Schmidt, M. Termansen, A. Timmermann, D. A. Wardle, 
P. Aastrup, and J.-C. Svenning. 2013. The role of biotic interactions in shaping distributions and realised assemblages of species: implications for species distribution modelling. Biological Reviews 88(1):15-30. http://dx.doi.org/10.1111/j.1469-185x.2012.00235.

$\underline{\mathrm{x}}$

Woodward, F. I. 1992. Predicting plant responses to global environmental change. New Phytologist 122(2):239-251. http://dx. doi.org/10.1111/j.1469-8137.1992.tb04228.x

Wright, S. J., H. C. Muller-Landau, and J. Schipper. 2009. The future of tropical species on a warmer planet. Conservation Biology 23(6):1418-1426. http://dx.doi.org/10.1111/j.1523-1739.2009.01337. $\underline{\mathrm{X}}$

Wu, H., J. Guiot, S. Brewer, Z. Guo, and C. Peng. 2007. Dominant factors controlling glacial and interglacial variations in the treeline elevation in tropical Africa. Proceedings of the National Academy of Sciences 104(23):9720-9724. http://dx.doi.org/10.1073/ pnas.0610109104

Zelnik, Y. R., S. Solomon, and G. Yaari. 2015. Species survival emerge from rare events of individual migration. Scientific Reports 5. http://dx.doi.org/10.1038/srep07877

Zhang, J.-T., B. Xu, and M. Li. 2013. Vegetation patterns and species diversity along elevational and disturbance gradients in the Baihua Mountain Reserve, Beijing, China. Mountain Research and Development 33(2):170-178. http://dx.doi.org/10.1659/mrdjournal-d-11-00042.1

Zobel, M., and M. Öpik. 2014. Plant and arbuscular mycorrhizal fungal (AMF) communities - which drives which? Journal of Vegetation Science 25(5):1133-1140. http://dx.doi.org/10.1111/ jvs. 12191 


\section{Appendix 1. An overview of evidence}

Here I summarize observations and evidence relevant to the ideas presented in the main text. This is not an exhaustive summary, but rather illustrates the nature and limitations of such evidence.

My method was to define some hypotheses and identify relevant observations. There are two fundamental hypotheses:

$\mathrm{H} 1$ - disturbance (reduced competition) permits species to occur at higher temperatures (lower elevations) than with greater competition.

$\mathrm{H} 2$ - disturbance (reduced competition) permits species to occur at lower temperatures (higher elevations) than with greater competition.

These hypotheses provide useful shorthand in classifying observations.

\section{Distributions}

Species common at high elevations in tropical mountains also occur locally, in disturbed areas, at much lower elevations (consistent with $\mathrm{H} 1$, see previous section). For example, the forest undergrowth around the Institute of Tropical Forest Conservation field station (where I worked until recently) at 2,300 $\mathrm{m}$ above sea level (a.s.I.) in the Bwindi Impenetrable National Park SW Uganda, burned in the late 1970s and now possesses vegetation typically associated with more pristine sites at higher elevations elsewhere in the region (Owiunji et al. 2005): e.g., tree heathers Erica trimera (Engl.) Beentje (more typically found close to the tree line at 3000-4000 $\mathrm{m}$ ), Hagenia abyssinica (Bruce) J. F. Gmel. (a tree recorded up to $3600 \mathrm{~m}$ ), and giant Lobelias (typical of the vegetation above $3000 \mathrm{~m}$, pers. obs.).

Many species are cultivated outside their natural range. Several alpine species for example are grown as ornamentals at much lower elevations and higher temperatures than occur in their natural range (Birks and Willis 2008). Van der Veken et al. (2008) found 260 of 357 native European plants (73\%) are sold well north (mean about $1000 \mathrm{~km}$ ) of their natural range suggesting an ability to grow in colder conditions when suitably tended (supporting $\mathrm{H} 2$ ). Live collections offer a resource for future study but interpretation of such data must be treated with caution 
Appendix 1. Disturbance and distributions - page 2

due to uncertainties about local growing conditions, provenance and selection effects.

In the boreal forests of Scandinavia Betula pubescens Ehrh. is "early successional" at low elevations but sometimes form an apparent climax at higher elevations, e.g., in (Kullman 2013) (consistent with H1). Many other examples relate to the tropics.

Polyscias fulva, a common fast growing tree species of mountain forest, occasionally occurs in heavily disturbed forest and open sites at much lower elevations - this relationship is sufficiently well established that when its pollen is recorded in palynological reconstructions at lower elevations it is readily interpreted as an indicator of disturbance rather than of cooler conditions (Morrison and Hamilton 1974). Several Ericaceae typically found above $3000 \mathrm{~m}$ also occur in secondary regrowth at much lower elevations (Marchant and Hooghiemstra 2001).

Similar behavior occurs in other Araliads, Moraceae and Urticaceae in other regions (A Gillison pers. comm.).

Ocotea usambarensis Engl. is a large slow-growing dense-timbered tree of primary mountain forests in tropical Africa. Despite lacking pioneer characters this species indicates past disturbance when seen at low elevation sites. Lovett (1996) examined vegetation elevation relationships in the Tanzanian highlands and based on his observations comments that $O$. usambarensis, and by implication other species, are "restricted to higher elevations because of competitive community dynamics, and not as a result of physical factors such as temperature" (an implication of $\mathrm{H} 1$ ).

Elsewhere, in the high elevation oak forests of Costa Rica, regrowth after clearance leads to high species numbers due to the influx of species from above the treeline (Kappelle et al. 1995). These additional species do not otherwise establish and grow in closed forest (consistent with $\mathrm{H} 1$ ).

Bussmann (2004) noted that landslides on tropical mountains are frequently colonized first by species from higher elevations rather than those from the immediate surroundings. Other observations also indicate that disturbance can lower the elevations at which boundaries between vegetation communities occur. In East Africa burning has lowered the high elevation forest "tree line" on many mountains (Hamilton and Perrott 1981) and tree-cover patches remain in higher sites protected from fire (e.g., Wesche 2003). On Kilimanjaro the Helichrysum vegetation 
Appendix 1. Disturbance and distributions - page 3

that would otherwise occur above the potential tree-line at around 4000 meters, remains common in burned areas even $800 \mathrm{~m}$ lower (Hemp 2006). Such tree-linelowering impacts occur worldwide (Smith and Young 1987, Korner 1998, Olivera et al. 2009, White 2013). All observations consistent with H1.

During periods of recurrent drought, when fires become more frequent, high elevation vegetation would - if consistent with $\mathrm{H} 1$ - be expected to expand into lower areas. Indeed, pollen cores reveal expansion of high-elevation vegetation in the East African Highlands (the upper Nile catchment) following periods when, according to ancient Egyptian texts, the Nile failed to flood for several consecutive years (Marchant and Hooghiemstra 2001).

Disturbances influence vegetation boundaries between types of forest too (as implied by $\mathrm{H} 1$ ). For example, the Caribbean pine forests of Hispaniola frequently occur just above mixed-species forests, but fires and landslides appear associated with lowered boundaries (Martin et al. 2011) with similar boundary dynamics reported from the Philippines (Kowal 1966 quoted in Martin et al. 2011).

Another example is East Africa's mountain bamboo Yushania alpina. Dominance at lower elevations appears associated with disturbance as noted on Kilimanjaro in Tanzania (e.g., Grimshaw 1999). Uganda's heavily disturbed Echuya Forest at 2260 to $2450 \mathrm{~m}$ is also dominated by bamboo though this occurs below the elevation range of the species elsewhere in the region (Morrison and Hamilton 1974). If disturbance "lowers" the mean per species elevation range (rather than broadening it near symmetrically as might occur if $\mathrm{H} 1$ and $\mathrm{H} 2$ are both true), then exploratory gradient analyses of the associated vegetation communities should indicate that the influence of elevation and disturbance on community composition are correlated. Such relationships do appear to occur, e.g. in Brazil's Atlantic forests (Eisenlohr et al. 2013), but further evaluation would be needed to exclude confounding factors.

Discussions with colleagues indicates that similar patterns of lower-elevation pioneers also occurring as higher-elevation late successional species are widespread, though the published literature remains sparse. For example, Alphitonia cf. excelsa (Rhamnaceae) a short-lived pioneer in the lowland forests of Papua New Guinea, also occurs as a local dominant in an apparently climax community on at 
Appendix 1. Disturbance and distributions - page 4

some exposed low montane sites characterized by Eocene limestone (A Gillison pers. comm.).

While these relatively informal observations are suggestive, they are not conclusive: we remain uncertain concerning the role of soil, microclimates and other factors in generating the observed distributions. Furthermore, we recognize that occurrence is not evidence of viability and persistence - a problem also noted in formal studies of species coexistence where a species occurrence may result from a declining or randomly fluctuating population, or may depend on propagules from a source population elsewhere studies (Siepielski and McPeek 2010).

\section{Successional traits}

In the examples mentioned thus far, species from higher-elevations appear to behave as effective pioneers in disturbed areas at lower-elevations (suggesting a situation more like that in figure $1 e$ than in figure $1 f$ in the main text). Such species may be a subset of the community with more pioneer like characteristics such as good dispersal abilities, but there are also indications that higher-elevation species may be better adapted to colonization than are lower-elevation species. There are plausible evolutionary explanations. Tree replacement dynamics in closed forests is typically a tree-gap-scale, process while fires and perhaps other larger scale events, appear more frequent above the treeline (Smith and Young 1987, Wesche et al. 2000, Sherman et al. 2008, Martin et al. 2011). Ancestral states may also play a role: biogeographic isolation from similar environments increases with elevation so the ancestral dispersal events able to establish a species on a new but similar tropical mountain site become more extreme with increased elevation (as an example consider the Hawaiian lobeliads which evolved from one ancestor adapted to high elevation forest clearings, swamps or grasslands similar to its nearest extant relatives in Africa Lobelia giberroa, L. columnaris and L. petiolata (Givnish et al. 2009)). There is also ecological evidence of such a pattern.

A study of 234 boreal and temperate tree species indicated that a greater proportion of species had early successional traits as latitude increased (supporting H1) (Morin and Chuine 2006). 
Appendix 1. Disturbance and distributions - page 5

A more recent study of plant functional traits and the distribution of 250 North American tree species used quantile regressions and found that while these species distributions overlap over vast regions -clear distributional patterns arise at the boundaries. Denser wooded species and larger seeded species, characteristics considered typical of late succession, appeared to be excluded at more northerly (colder) conditions where only low density wood and small seeds (properties typical of pioneer species) occurred (Stahl et al. 2014). These patterns are consistent with H1.

Other evaluations of seed size with elevation and latitude - with smaller seeds implying pioneer type behavior - also fit the H1 pattern. For example, Baker (1972) found that per species seed weight declined with elevation on Californian mountains, while Moles et al. (2007) used a global data set to identify a 320 -fold reduction in geometric mean seed mass from the equator to a latitude of 60 degrees. There are various possible explanations for these patterns but the outcome is that a comparison of higher elevation and lower elevation species communities will indicate more pioneer type characteristics in the former.

\section{Experiments}

Woodward (1975) developed studies that indicated that the decrease of temperature associated with a $250 \mathrm{~m}$ variation in elevation is sufficient to reverse the competitive outcome between two Sedum species that can establish, grow and persist across this entire range in the absence of competition in Britain: Sedum rosea (L.) Scop, which dominates at higher elevations and $S$. telephium $\mathrm{L}$., which is more common at lower elevations. A subsequent study that established populations at different elevations predicted that $S$. rosea and $S$. telephium would be excluded by competition at lower and higher elevation sites respectively: while this was born out for $S$. rosea (taking 5 years), S. telephium persisted for 15 years though the population declined over this period (Woodward 1992). These studies are all in agreement with $\mathrm{H} 1$ and $\mathrm{H} 2$.

A review of transplant studies has summarized the nature of the elevation limits implied (see main text) (Hargreaves et al. 2014). Direct examination of the impacts of warming of boreal communities in Norway indicate that increasing temperatures 
Appendix 1. Disturbance and distributions - page 6

also increase and modify competitive interactions consistent with $\mathrm{H} 1$ (Klanderud and Totland 2005, Olsen and Klanderud 2014). Looking to other systems I note one experimental study of biofilm-dwelling ciliates that found that disturbance reduced some effects of artificial warming on community change, again consistent with $\mathrm{H} 1$ (Marcus et al. 2014). Microcosm studies with single species and species combinations have highlighted that competitive hierarchies determine speciestemperature distributions for fruit flies indicating that similar dynamics operate in these taxa under these conditions (Davis et al. 1998).

\section{LITERATURE CITED}

Baker, H. G. 1972. Seed weight in relation to environmental conditions in California. Ecology 53:9971010.

Birks, H. J. B., and K. J. Willis. 2008. Alpines, trees, and refugia in Europe. Plant Ecology \& Diversity 1:147-160.

Bussmann, R. W. 2004. Regeneration and succession patterns in African, Andean and Pacific tropical mountain forests: the role of natural and anthropogenic disturbance. Lyonia 6:93-111.

Davis, A. J., L. S. Jenkinson, J. H. Lawton, B. Shorrocks, and S. Wood. 1998. Making mistakes when predicting shifts in species range in response to global warming. Nature 391:783-786.

Eisenlohr, P. V., L. F. Alves, L. C. Bernacci, M. C. Padgurschi, R. B. Torres, E. M. Prata, F. A. M. dos Santos, M. A. Assis, E. Ramos, and A. L. C. Rochelle. 2013. Disturbances, elevation, topography and spatial proximity drive vegetation patterns along an altitudinal gradient of a top biodiversity hotspot. Biodiversity and conservation 22:2767-2783.

Givnish, T. J., K. C. Millam, A. R. Mast, T. B. Paterson, T. J. Theim, A. L. Hipp, J. M. Henss, J. F. Smith, K. R. Wood, and K. J. Sytsma. 2009. Origin, adaptive radiation and diversification of the Hawaiian lobeliads (Asterales: Campanulaceae). Proceedings of the Royal Society B: Biological Sciences 276:407-416.

Grimshaw, J. M. 1999. The afromontane bamboo, Yushania alpina, on Kilimanjaro. Journal of East African Natural History 88:79-83.

Hamilton, A., and R. Perrott. 1981. A study of altitudinal zonation in the montane forest belt of Mt. Elgon, Kenya/Uganda. Vegetatio 45:107-125.

Hargreaves, A. L., K. E. Samis, and C. G. Eckert. 2014. Are species' range limits simply niche limits writ large? A review of transplant experiments beyond the range. The American Naturalist 183:157-173.

Hemp, A. 2006. Vegetation of Kilimanjaro: hidden endemics and missing bamboo. African Journal of Ecology 44:305-328.

Kappelle, M., P. F. Kennis, and R. J. de Vries. 1995. Changes in diversity along a successional gradient in a Costa Rican upper montane Quercus forest. Biodiversity \& Conservation 4:10-34.

Klanderud, K., and $\varnothing$. Totland. 2005. Simulated climate change altered dominance hierarchies and diversity of an alpine biodiversity hotspot. Ecology 86:2047-2054.

Korner, C. 1998. A re-assessment of high elevation treeline positions and their explanation. Oecologia 115:445-459.

Kullman, L. 2013. Ecological tree line history and palaeoclimate-review of megafossil evidence from the Swedish Scandes. Boreas 42:555-567. 
Lovett, J. C. 1996. Elevational and latitudinal changes in tree associations and diversity in the Eastern Arc mountains of Tanzania. Journal of Tropical Ecology 12:629-630.

Marchant, R., and H. Hooghiemstra. 2001. A Response to "Climate of East Africa 6000 14C yr B.P. as Inferred from Pollen Data" by Peyron et al. (2000). Quaternary Research 56:133-135.

Marcus, H., J. K. Wey, H. Norf, and M. Weitere. 2014. Disturbance alters the response of consumer communities towards warming: a mesocosm study with biofilm-dwelling ciliates. Ecosphere 5:article 10.

Martin, P. H., T. J. Fahey, and R. E. Sherman. 2011. Vegetation zonation in a neotropical montane forest: environment, disturbance and ecotones. Biotropica 43:533-543.

Moles, A. T., D. D. Ackerly, J. C. Tweddle, J. B. Dickie, R. Smith, M. R. Leishman, M. M. Mayfield, A. Pitman, J. T. Wood, and M. Westoby. 2007. Global patterns in seed size. Global Ecology and Biogeography 16:109-116.

Morin, X., and I. Chuine. 2006. Niche breadth, competitive strength and range size of tree species: a trade-off based framework to understand species distribution. Ecology Letters 9:185-195.

Morrison, M. E., and A. C. Hamilton. 1974. Vegetation and climate in the uplands of south-western Uganda during the later Pleistocene Period: II. Forest clearance and other vegetational changes in the Rukiga Highlands during the past 8000 Years. The Journal of Ecology:1-31.

Olivera, M. M., J. F. Duivenvoorden, and H. Hooghiemstra. 2009. Pollen rain and pollen representation across a forest-páramo ecotone in northern Ecuador. Review of Palaeobotany and Palynology 157:285-300.

Olsen, S. L., and K. Klanderud. 2014. Biotic interactions limit species richness in an alpine plant community, especially under experimental warming. Oikos 123:71-78.

Owiunji, I., D. Nkuutu, D. Kujirakwinja, I. Liengola, A. Plumptre, A. Nsanzurwimo, K. Fawcett, M. Gray, and A. McNeilage. 2005. The biodiversity of the Virunga Volcanoes. Unpublished report, Wildlife Conservation Society, New York.

Sherman, R. E., P. H. Martin, T. J. Fahey, and S. D. Degloria. 2008. Fire and vegetation dynamics in high-elevation neotropical montane forests of the Dominican Republic. Ambio 37:535-541.

Siepielski, A. M., and M. A. McPeek. 2010. On the evidence for species coexistence: a critique of the coexistence program. Ecology 91:3153-3164.

Smith, A. P., and T. P. Young. 1987. Tropical alpine plant ecology. Annual Review of Ecology and Systematics 18:137-158.

Stahl, U., B. Reu, and C. Wirth. 2014. Predicting species' range limits from functional traits for the tree flora of North America. Proceedings of the National Academy of Sciences 111:1373913744.

Van der Veken, S., M. Hermy, M. Vellend, A. Knapen, and K. Verheyen. 2008. Garden plants get a head start on climate change. Frontiers in Ecology and the Environment 6:212-216.

Wesche, K. 2003. The importance of occasional droughts for afroalpine landscape ecology. Journal of Tropical Ecology 19:197-208.

Wesche, K., G. Miehe, and M. Kaeppeli. 2000. The significance of fire for afroalpine ericaceous vegetation. Mountain Research and Development 20:340-347.

White, S. 2013. Grass páramo as hunter-gatherer landscape. The Holocene 23:898-915.

Woodward, F. 1975. The climatic control of the altitudinal distribution of Sedum rosea (L.) Scop. and S. telephium L. New Phytologist 74:335-348.

Woodward, F. 1992. Predicting plant responses to global environmental change. New Phytologist 122:239-251. 